Int. J. Dev. Biol. 53: 355-370 (2009)

doi: $10.1387 / \mathrm{ijdb} .082690 \mathrm{mv}$

\title{
Role of polycomb proteins Ring1A and Ring1B in the epigenetic regulation of gene expression
}

\author{
MIGUEL VIDAL* \\ Department of Developmental and Cell Biology, Centro de Investigaciones Biológicas, CSIC, Madrid, Spain
}

\begin{abstract}
Generation of cell diversity depends on epigenetic regulatory mechanisms. Polycomb group (PcG) proteins are central components of epigenetic regulation in metazoans. The system, initially associated with transcriptional program stability during development, is also involved in the regulation of other processes, such as maintenance of stem cell pluripotency and cell proliferation. PcG regulation involves chromatin modifications through covalent histone modifications. One of these modifications, the monoubiquitylation of the H2A histone, depends on Ring 1 proteins, which are essential for development in insects and mammals. In murine embryonic stem cells, Ring1A and Ring1B-dependent ubiquitylation of H2A is linked to repression of transcriptional initiation. Studies in mammalian cells have found a multiplicity of protein complexes containing Ring1A and Ring1B, suggesting an expanded regulatory role for Ring1A, Ring1B proteins in the epigenetic regulation of gene expression.
\end{abstract}

KEY WORDS: Ring1A, Ring1B, polycomb, H2A ubiquitylation, epigenetic regulation

Ring1A/Ring1 and its paralog Ring1B/Rnf2 are core components of the mammalian Polycomb system, which is one of the epigenetic regulators of cell diversity generation during embryonic development and tissue maintenance during adult life (Rajasekhar, 2007; Sparmann, 2006). Although initially identified during genetic studies of developmental regulation of the fruit fly $D$. melanogaster, the Polycomb group (PcG) of genes is represented throughout all metazoans (Ringrose, 2004; Schuettengruber, 2007; Whitcomb, 2007). PcG was named after the founding member, Polycomb $(P c)$, a term that refers to the extra number of sexual combs found in PC mutant fly males. During this genetic analysis of Drosophila development, another group of genes, the trithorax group (trxG) was identified because of their ability to counteract the activity of PcG genes (Ringrose, 2004; Grimaud, 2006; Schwartz, 2007).

PcG genes encode subunits of multiprotein complexes with a role as transcriptional repressors (Table 1). In mammals, developmental processes controlled by PcG genes include specification of the antero-posterior axis, monoallelic expression of imprinted genes and self-renewal of embryonic and somatic stem cells. In addition, deregulation of the Polycomb system is often associated to neoplastic events and tumor formation (ValkLingbeek, 2004; Sparmann, 2006; Rajasekhar, 2007).

Polycomb complexes act, at least in part, through chemical modification of histones, one of the mechanisms involved in the multilayered, interdependent, processes that regulate the selective use of the genome (Shilatifard, 2006; Taverna, 2007). Two types of postranslational modifications of histones, associated to transcriptional repression, are dependent on PcG complexes (Polycomb repressive complexes, PRCs). One of these covalent modifications, trimethylation of the lysine 27 of histone $\mathrm{H} 3$ (H3K27me3), is catalyzed by a histone methyltransferase and associated cofactors that appeared earliest in evolution and are found in plants and animals (Cao, 2004). A second one, monoubiquitylation of the lysine 119 of histone H2A (H2K119Ub1), is mediated by a set of RING finger proteins present in insects and vertebrates, but not in plants or worms (de Napoles, 2004; Wang, 2004). Ring1A/Ring1 and Ring1B/Rnf2 are the E3 protein ligases responsible for PcG-dependent ubiquitylation of histone $\mathrm{H} 2 \mathrm{~A}$. Both histone modifying activities are found in independent complexes which act coordinately (Cao, 2005). Methylation of H3K27, by the so-called initiation complex, precedes ubiquityilation of $\mathrm{H} 2 \mathrm{~A}$ by the maintenance complex, in an oversimplified, but useful,

\footnotetext{
Abbreviations used in this paper: $\mathrm{PcG}$, polycomb group; PRC, polycomb repressive complex; trxG, trithorax group.
}

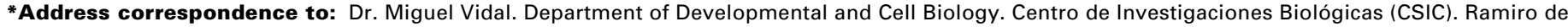
Maeztu, 9. 28040 Madrid, Spain. Fax: +34-91-536-0432. e-mail: mvidal@cib.csic.es
}

Supplementary Material for this paper (a multiple sequence alignment) is available at: http://dx.doi.org/10.1387/ijdb.082690mv

Published online: 29 April 2009.

ISSN: Online 1696-3547, Print 0214-6282

(c) 2009 UBC Press

Printed in Spain 


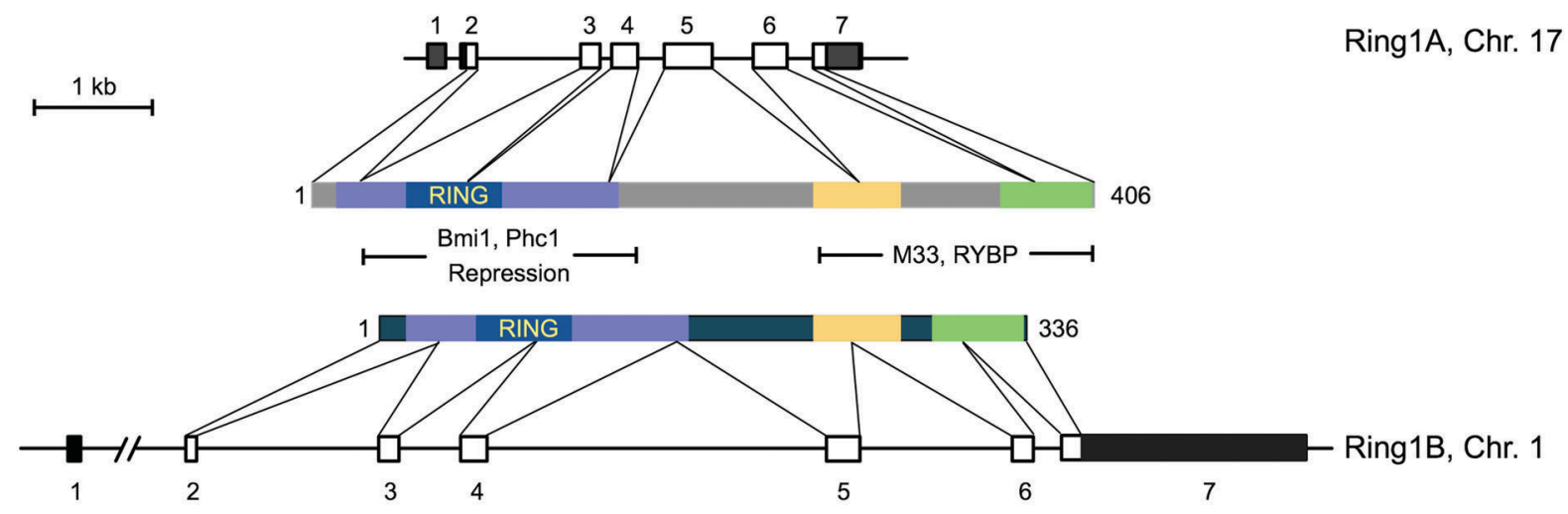

Fig. 1. Genomic structure of the murine Ring 1 A and Ring1B loci and of the encoded cDNAs. Exons are represented as boxes whose coding parts are empty and 5' and 3' UTR are filled. The first intervening sequence in the Ring1 B locus, interrupted by slashes, is $22 \mathrm{~kb}$ in length and it has be redrawn to the proximity of exon 2. Conserved regions in Ring $1 A$ and Ring1B, including the RING fingers, are depicted as colored segments. Proteins binding to the indicated regions, and the repressing domain of Ring $1 A$ are indicated.

view of how the Polycomb system works (Sparmann, 2006; Schuettengruber, 2007).

Recently three lines of investigation are paving the ground for elucidating PcG function most of which, up to now, has come from genetic analysis: (i) characterization of the enzymatic activities of PcG products (ii) proteomic analysis of PcG complexes and (iii) identification of their target genes. In this Review, I will consider the biochemical intricacies of complexes that contain Ring1A/ Ring1 and Ring1B/Rnf2 proteins, thereafter referred to as Ring1 $\mathrm{A}$ and Ring1B. I will then describe their activities as monoubiquitin $\mathrm{H} 2 \mathrm{~A}$ ligases and the mechanisms of transcriptional control affected by this histone modification. I will conclude by summarizing the major biological processes on which the mammalian Ring1 proteins have been found to participate, including their role in stem cell maintenance and tissue homeostasis.

\section{Ring1A and Ring1B are RING finger transcriptional repressors}

Ring1 A and Ring1B were found in searches for components of mammalian Polycomb complexes using the yeast two-hybrid system to identify interacting partners of vertebrate homologs of Drosophila PC. Murine Ring1A and Ring1B were identified using the transcriptionally repressive domain of $M 33 / \mathrm{Cb} 22$ (Schoorlemmer, 1997). Human Ring1A was similarly isolated using a full length form of a Pc homolog in Xenopus, Cbx4 (Satijn, 1997). The Ring1A cDNAs were found to be identical to the product of one of a set of "Really INteresting Genes" previously identified during a search for transcripts from the major histocompatibility complex (Hanson, 1991; Lovering, 1993; Saurin, 1996). Ring1B cDNA encodes a related, but distinct protein (Schoorlemmer et al., 1997), and subsequently was also identified in similar molecular screens that used a vertebrate homolog of Drosophila PSC as a bait (Suzuki, 2002).

Paradoxically, at the time of Ring1A and Ring1B isolation there was no molecularly characterized Drosophila PcG gene encoding a Ring1 ortholog. However, loss of function of both genes in the mouse showed alterations in the axial skeleton similar to those seen in other PcG mutant mouse lines (del Mar Lorente, 2000; Suzuki, 2002). Eventually, Sex combs extra (Sce), a PcG gene identified in a genetic screen in Drosophila, was found to encode the ortholog of vertebrate Ring 1 products (Fritsch, 2003; Gorfinkiel, 2004).

The initially isolated Ring $1 A$ cDNAs encoded for a 377 amino acid protein (Lovering, 1993; Schoorlemmer, 1997; Satijn, 1997). Subsequent cloning of 5' ends of Ring1A cDNA and comparison of their sequences with that of genomic clones (chromosome 16 in humans, chromosome 17 in mouse) provided evidence for a full length protein of 406 amino acids (Schoorlemmer, 1997). Sequence analysis of Ring1A identified a N-terminal Cys-rich domain conserved among many other proteins that defined a motif termed RING finger (Lovering, 1993). This new protein motif also contains histidine and is organized as a three-stranded antiparallel $\beta$-sheet, two $\mathrm{Zn}^{2+}$ binding loops, and an $\alpha$-helix following the second $\beta$-strand. $\mathrm{Zn}^{2+}$ binding is needed for the proper folding of the RING motif (Borden, 2000). The cross-braced arrangement of $\mathrm{Zn}^{2+}$ binding by the conserved cysteine and histidine residues (either in the $\mathrm{C} 3 \mathrm{HC} 4$ or the $\mathrm{C} 3 \mathrm{H} 2 \mathrm{C} 3$ form), sets this domain apart from other cysteine-histidine zinc binding motifs, such as PHD (Plant homeodomain) or LIM (Lisl1/IsI-1/Mec3) domains (Capili, 2001). Thus, the first and third pair of $Z n$ ligands share $Z n 1$ and the second and fourth pair of $\mathrm{Zn}$ ligands share $\mathrm{Zn}$ 2. The RING fingers of Ring1A and Ring1B are of the C3HC4 type, and threedimensional structures have recently been derived for that of Ring1B ( $\mathrm{Li}, 2006)$. The RING motif is also found in other PcG products, namely the family of Polycomb group RING finger (Pcgf) proteins, the homologs of Drosophila PSC (Table 1).

The murine or human Ring1B genes (both located on chromosome 1) encode a 336 amino acid protein. The seven exon transcriptional unit, however, is much less compact than that of the Ring $1 A$ genes, mostly because the transcription start site is separated by a large intervening sequence from the first coding exon (Fig. 1). Comparison of Ring1A and Ring1B protein sequences identifies three conserved regions (Fig. 1). The largest, at the N-terminal end of the proteins spans the RING finger, and is separated from other two regions by a nonconserved sequence. Biophysical analysis of a fragment of Ring1B/Rnf2 encompassing the two $\mathrm{C}$-terminal conserved regions (amino acids 222-336) shows that it is a well formed, globular, structure with a high content of $\alpha$-helix and $\beta$-sheets that forms homodimers 
TABLE 1

\section{POLYCOMB PROTEINS}

\begin{tabular}{|c|c|c|}
\hline Drosophila & Humans & Domains, activities \\
\hline \multicolumn{3}{|l|}{ PRC2 (initiation complex) } \\
\hline Esc & EED & WD40 \\
\hline$E(z)$ & $\mathrm{EZH} 2, \mathrm{EZH} 1$ & SET, H3K27 methyltransferase \\
\hline $\mathrm{Su}(\mathrm{z}) 12$ & SUZ12 & FCS-type Zn finger, RNA binding \\
\hline \multicolumn{3}{|l|}{ PRC1 (maintenance complex) } \\
\hline Polycomb, PC & М33/CBX2†, РC2/CBX4, РC3/CBX8, СBX7, СBX6* & Chromodomain, binding to $\mathrm{H} 3 \mathrm{~K} 27 \mathrm{me} 3$ \\
\hline Polyhomeotic, $\mathrm{PH}$ & $\mathrm{PH} 1 / \mathrm{PHC} 1, \mathrm{PH} 2 / \mathrm{PHC} 2, \mathrm{PH} 3 / \mathrm{PHC} 3$ & SAM, oligomerization; FCS-type Zn finger, RNA binding \\
\hline Posterior sex combs, PSC & BM1/PCGF4, MEL18/PCGF2, NSPC1/PCGF1, MBLR/PCGF6, PCGF5*, PCGF3* & RING finger \\
\hline Sex combs extra, Sce/dRING & RING1A/RING1, RING1B/RNF2 & RING finger, E3 ubiquitin ligase for $\mathrm{H} 2 \mathrm{~A}$ \\
\hline Sex combs on midleg, SCM & SCMH1, SCMH2* & MBT, histone binding; SAM, oligomerization \\
\hline \multicolumn{3}{|l|}{ Other } \\
\hline Pleiohomeotic, $\mathrm{PHO}$ & YY1 & Zn finger, DNA binding \\
\hline Pleiohomeotic-like, PHO-L & YY1 & Zn finger, DNA binding \\
\hline
\end{tabular}

tIn protein names given in pairs, the latter, after the slash, corresponds to the official nomenclature.

*Homologs without evidence for a Polycomb function.

through the docking of preformed monomers (Czypionka, 2007). Conservation of these $\mathrm{C}$-terminal regions may be imposed by a given folding needed for specific contacts with chromodomaincontaining proteins [for instance, M33/Cbx2, (Schoorlemmer, 1997)] or the Ring1 and YY1 binding protein (García, 1999; Neira et al., 2009) that occur through these regions of Ring1 proteins.

When fused to a DNA binding domain such as that of the yeast GAL4 transcription factor, both Ring1A and Ring1B acts as transcriptional reppressors of reporter constructs that have GAL4 operators (Schoorlemmer, 1997; Wong, 2007). These studies, however, show contrasting results about the role of the RING fingers, which appear essential for Ring1A repression but dispensable for Ring1B repression.

\section{Evolutionary conservation of Ring1 proteins}

Searches for homologs of Ring1A and Ring1B proteins among multicellular organisms by using a sequence-similarity method between full length sequences, show single copies of the Ring1 proteins in invertebrates and two copies only in vertebrates. This contrasts with a multiplicity of paralogs (Table 1) identified in vertebrates and plants for several other PcG proteins. For in-
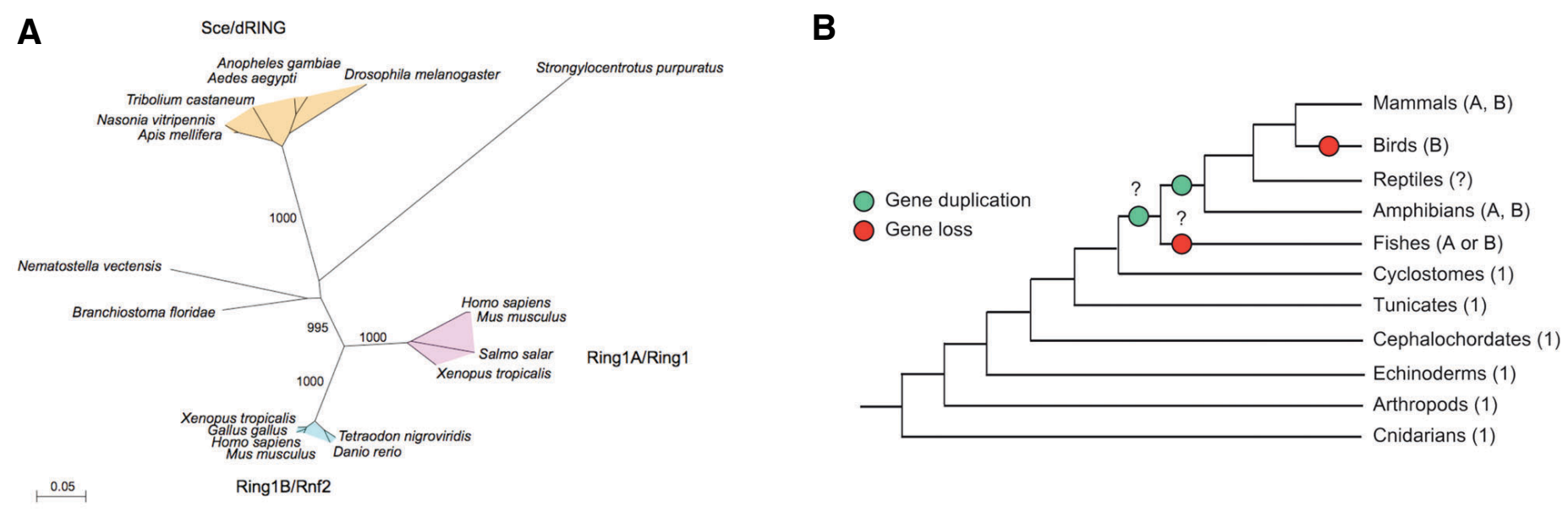

Fig. 2. Conservation of Ring1 proteins during evolution. (A) Phylogenetic tree of full length Ring1 proteins showing bootstrap confidence levels of the reliability of grouping in the various branches. The scale bar indicates distances calculated with JTT substitution model implemented in the PHYLIP package. The tree does not include all known mammalian sequences (because of extreme similarity) and only those of human and mouse are plotted for simplicity. (B) Canonical tree of life (http://tolweb.org/tree/phylogeny.html) indicating the number and type of Ring 1 proteins (A and $B$ denote Ring1A type and Ring1B type, respectively) among animal groups. A number 1 indicates only one protein that is not assigned to either Ring $1 A$ or Ring1B type. Green and red dots indicate the positions at which gene duplication and loss, respectively, may have occurred during evolution. The species considered for each of the animal groups shown are: Homo sapiens and Mus musculus (Mammals), Gallus gallus (Birds), Xenopus tropicales (Amphibians), Tetraodon nigroviridis, Danio rerio and Salmo salar (Fishes), Branchiostoma floridae (Cephalocordates), Apis melifera, Nasonia vitripennis, Aedes aegypti, Anopheles gambiae and Tribolium castaneum (Arthropods), Strongylocentrus purpuratus (Echinoderms) and Nematostella vectensis (Cnidarians). 
stance, the family of $\mathrm{PC}$ paralogs has five members in mammals, M33/Cbx2, Pc2/Cbx4, Cbx6, Cbx7 and Pc3/Cbx8, whereas that of PSC has six, Nspc1/Pcgf1, Mel18/Pcgf2, Pcgf3, Bmi1/Pcgf4, Pcgf5 and MBLR/Pcgf6. Sequence similarity analysis of Ring1 paralogs groups most species around three major categories of Ring1 proteins: insects, which express the Drosophila Sce/dRING type, and vertebrates that express either Ring1A or Ring1B-type proteins or both (Fig. 2). No Ring1 homologs have been found in plants or in worms, although sequences encoding RING finger domains related to those of Ring1 proteins have been identified (not shown and Karakuzu, 2009).

The high degree of conservation among Ring1 orthologs can be seen in the phylogenetic tree constructed with the full length Ring1 proteins sequences (Fig. 2A) and is much higher than that found for the orthologs of any other PcG protein (Whitcomb, 2007). Alignment of Ring1 protein sequences allows to easily identify the conserved $\mathrm{N}$-terminal and the two $\mathrm{C}$-terminal regions (supplementary Fig. 1). In insects, the Ring1 proteins show a distinctive long linker sequence separating the $\mathrm{N}$-terminal region spanning the RING finger motif from the C-terminal conserved regions. In agreement with the high degree of structural conservation, the phenotype of a Sce/dRing mutation in Drosophila larvae is substantially rescued by the ectopic expression of the murine Ring1A protein (Gorfinkiel, 2004). Protochordates (Branchiostoma) and Teleostei fishes express only one Ring1 protein. In the case of fishes it is either of the Ring1B type (Tetraodon, Danio) or the Ring1A type (Salmo). If Salmo only has a Ring1 protein (its genome is not fully sequenced yet) and it is an ortholog of the Ring 1 protein of other Teleostei it would imply that a Ring1 gene was duplicated after the appearance of fishes and was selectively lost at Birds (Gallus) or monotreme mammals (Ornithorhynchus) which have a single Ring1 protein, of the Ring1Btype. Only eutherian mammals and amphibia (Xenopus) have Ring1 proteins of both types. A tree of life showing the possible duplication and loss of Ring1 genes during evolution is shown in Fig. 2B.

\section{Ring1A, Ring1B-containing complexes}

Genetic analysis in Drosophila provided evidence for synergistic effects in compound PcG mutants, which suggested that PcG products may act as part of multiprotein complexes. On this basis, initial characterization of PcG complexes relied on the use of yeast-two hybrid interaction assays and coimmunoprecipitation assays that involved known PcG subunits. However, Ring1A and Ring1B have also been isolated as interactors in yeast-two hybrid screens that used non-PcG proteins as baits. The interactor pairs thus identified, are usually proteins that associate directly to each other, as validated in pull down assays that use recombinant forms of the proteins. Table 2 summarizes vertebrate proteins that associate directly to either or both of the Ring1 proteins. Many other proteins associate indirectly, as subunits of Ring1 proteinscontaining complexes, and are described below. Most direct interactors, including Ring1 proteins themselves (Satijn, 1999), are PcG products (M33, Pc2, Pc3, Bmi1, Ph2, etc (Satijn, 1997; Schoorlemmer et al., 1997; Cao, 2005; Hemenway, 1998; Satijn, 1999; Hemenway, 2000)] or their homologs [NsPc1, MBLR (Akasaka, 2002; Gearhart, 2006)]. Others are transcriptional repressors such as RYBP (García, 1999), or proteins that interact
TABLE 2

\section{PROTEINS THAT INTERACT DIRECTLY WITH RING1A AND/OR RING1B}

\begin{tabular}{|c|c|c|}
\hline Ring1 protein & Interactor & Reference \\
\hline Ring1A/Ring1 & $\begin{array}{l}\text { M33/Cbx2 } \\
\text { Pc2/Cbx4 } \\
\text { BMI1/PCGF4 } \\
\text { RYBP } \\
\text { KyoT2 } \\
\text { NSPC1/PCGF1 } \\
\text { PH2/PHC2 } \\
\text { PC3/CBX8 } \\
\text { RING1A/RING1 }\end{array}$ & $\begin{array}{l}\text { Schoorlemmer, } 1997 \\
\text { Satijn, } 1997 \\
\text { Satijn and Otte, } 1999 \\
\text { García, } 1999 \\
\text { Qin, } 2002 \\
\text { Gearhart, } 2006 \\
\text { Cao, 2005 } \\
\text { Hemenway, } 2000 \\
\text { Satijn and Otte, } 1999\end{array}$ \\
\hline Ring1B/Rnf2 & $\begin{array}{l}\text { BMl1/PCGF4 } \\
\text { Mblr/Pcgf6 } \\
\text { Mel18/Pcgf2 } \\
\text { PH2/PHC2 } \\
\text { PC3/CBX8 } \\
\text { CP-2/Tcfpcf2 } \\
\text { Fbxl10/Jhdm1B } \\
\text { PHB } \\
\text { RYBP } \\
\text { NSPC1/PCGF1 } \\
\text { RING1A/RING1 } \\
\text { HIP2/UBE2K } \\
\text { TBP-1/PSMC3 }\end{array}$ & $\begin{array}{l}\text { Hemenway, } 1998 \\
\text { Akasaka, } 2002 \\
\text { Suzuki, } 2002 \\
\text { Hemenway, } 1998 \\
\text { Hemenway, } 2000 \\
\text { Tuckfield, } 2002 \\
\text { Sánchez, } 2007 \\
\text { Choi, 2007 } \\
\text { Gearhart, } 2006 \\
\text { Gearhart, } 2006 \\
\text { Gearhart, } 2006 \\
\text { Lee, } 2003 \\
\text { Lee, } 2005\end{array}$ \\
\hline
\end{tabular}

with transcription factors, such as KyoT2 (Qin, 2004) or DNA binding proteins as the ubiquitously expressed transcriptional CP-2/Tcfpcf2 (Tuckfield, 2002). Other interactors are involved in ubiquitylation reactions [the E2 protein ligase Hip2/Ube2k (Lee, 2001)] or belong to the regulatory subunit of the proteasome [TBP-1/PSMC3 (Lee, 2005)]. However, not all of these interactors have appeared among the subunits of purified Ring1A-Ring1Bcontaining complexes (see Table 3 ), isolated in tag-based approaches. In these, a tagged form of the protein of interest is expressed in tissue culture cells or fly embryos to assist in the efficient affinity-based isolation (using antibodies or interacting proteins coupled to a solid phase) of complexes that contain the tagged protein. The subunits in these complexes mixtures are identified by mass spectrometry analysis. Table 3 summarizes the subunits that have been identified in these tag-based isolation approaches that contain Ring1A, Ring1B or both.

\section{Ring1 proteins are core subunits of Polycomb Repres- sive Complex 1}

The isolation of the first Ring1-containing complex used extracts from early $D$. melanogaster embryos expressing taggedPcG subunits (FLAG-tagged PH or FLAG-tagged PSC). The complex thus isolated was termed Polycomb repressive complex 1 (PRC1) (Shao, 1999; Saurin, 2001), and in addition to PH and PSC contained the PcG products PC and Sce/dRING. Many other polypeptides not known as PcG products, copurified with FLAG$\mathrm{PH}$ or FLAG-PSC, including some components of the transcription initiation machinery (Saurin, 2001). Complexes isolated using similar approaches with human tissue culture cells, however, contained fewer subunits, most of them PcG products (Levine, 2002). Thus, human PRC1 subunits include homologs of $P C$ (M33/CBX2 and PC3/CBX8), of PSC (BMI1/PCGF4), Polyhomeotic (HPH1/PHC1, HPH2/PHC2 and HPH3/PHC3), and of Sce (RING1A and RING1B) together with substoichiometric amounts of another PcG product, the homolog of SMC (SCMH1) and of a few non PcG subunits (Levine, 2002).

Purified Drosophila PRC1 interferes with the activity of SWI/ 
SNF chromatin remodelers in a plasmid supercoiling assay (Shao, 1999). The smallest stable PRC1 subcomplex that still blocks SWI/SNF contains the PcG subunits PC, PH, PSC and Sce/ dRING (Francis, 2001b), all of which have homologs (Table 1) in human PRC1 (Levine, 2002). Therefore, these subunits are considered the core components of PRC1. Similar PRC1 complexes, differing in the core subunit homologs composition, perhaps a reflection of their relative abundance in the cell type used, have been isolated using tagged MEL18/PCGF2, BMI1/PCGF4 or CBX8/Pc3 subunits (Wiederschain, 2007; Dietrich, 2007). In every case, the mammalian version of PRC1 lacked most of nonPcG subunits found in Drosophila PRC1. One puzzling observation about the mammalian PRC1 complex is the absence of DNAbinding proteins that may assist on specific recruitment to targets. Up to now, only histone-binding motifs, such as the chromodomain present in PC homologs (Table 1), are known to be involved in recruiting, although some evidence points at alternative mechanisms (see below).

Ring1 subunits play a role in the stability of PRC1 complexes. For instance, the Drosophila core PRC1 complex is only stable if Sce/dRING1 is present (Francis, 2001b). In line with this observation, the inactivation of Ring1B in murine embryonic stem ES cells is associated to a dramatic decrease of the stationary levels of core PRC1 subunits (Leeb, 2007; Endoh, 2008). It is possible that the ability of Ring 1 proteins to directly contact each of the other core subunits (Hemenway, 1998; Satijn, 1999; Cao, 2005; Wei, 2006) may be the basis for their stable assembly in a complex.

\section{Other Ring1A-Ring1B containing complexes}

Ring1 A and Ring1B have also been found in molecular assemblies distinct from PRC1, together with many other polypeptdies with a role in transcriptional regulation (Table 3 ). The complexes, identified by proteomic approaches, have been isolated by pulling a variety of tagged subunits such as E2F6 (Ogawa, 2002), a member of the E2F family of transcription factors (Trimarchi, 2002), the histone demethylase SMCX/KDM5CA (Tahiliani, 2007)), the corepressor BCOR (Gearhart, 2006), the histone-binding WD40-repeat protein WDR5 (Dou, 2005) or ENL (Mueller, 2007), a protein fused to the histone H3K4 methyltransferase MII in a number of leukemias (Krivtsov, 2007). When tagged-PcG subunits were used, complexes more related to $P R C 1$ have been isolated. For instance, those purified through BMI1 (Levine, 2002; Wiederschain, 2007), MEL18 (Wiederschain, 2007; Elderkin, 2007), M33 (Levine, 2002) or PC3 (Dietrich, 2007). However, Ring1A, Ring1B and associated components isolated by pulling out NSPC1 (Gearhart, 2006) revealed a complex different from $P R C 1$. Together, these observations suggest that Ring1A and Ring1B are represented more frequently than any other PcG component in complexes involved in transcriptional control. This notion is confirmed by the variety of transcriptional regulators found to copurify with Ring1B (Sánchez, 2007), that includes most other interactors identified in previous purification schemes and some additional ones. It is important to note that the proteins thus identified are often part of several complexes that share the tagged subunit. Mass spectrometry analysis of Ring1B-associated polypeptides in a murine erythroleukemic cell line (Sánchez, 2007) suggests that PRC1 subunits are abundantly represented, but clearly they are not alone among the most abundant ones. Thus, together with PRC1, one or more complexes containing subunits identified in a E2F6 complex, and in a BcoR-Fbxl10 complex are equally abundant. Other enriched subunits belong to assembles not fully characterized. It is likely that similar purification schemes that use other cell types will render similar sets of proteins, but it is also conceivable that new sets of Ring1ARing1B containing complexes are uncovered.

Among the subunities found to copurify with Ring1 proteins some have known/suspected enzymatic activities as chromatin modifiers: for instance, histone demethylases (Lsd1/Kdm1, Fbxl10/ $\mathrm{Kdm} 2 \mathrm{~b}, \mathrm{SCMX} / \mathrm{KDM} 5 \mathrm{~B}$ ), histone methyltransferases (the heterodimeric GLP/EHMT- G9a/EHMT2 and DOT1L), protein kinases (regulatory and catalytic subunits of casein kinase 2) or histone deacetylases (HDAC1, HDAC2). Also found are DNAbinding proteins such as the heterodimers E2F6/DP1 and MAX/ MGA; other subunits are corepressors, such as BCOR and NCOR1, that associate to to the DNA binding proteins BCL6 and REST1, respectively. Histone binding motifs are present in a number of subunits: chromobox in HP1 (in addition to Polycomb paralogs), MBT domains in L3mbt2, WD40 repeats in Wdr5,

\section{TABLE 3}

\section{PROTEINS IDENTIFIED IN RING1A, RING1B-CONTAINING COMPLEXES}

\begin{tabular}{|c|c|c|c|c|}
\hline Tagged-subunit & affintiy tag & Co-purified subunits & Cell type & reference \\
\hline BMI1/PCGF4 & $6 \times \mathrm{His}+\mathrm{FLAG}$ & PHC3, PHC2, PHC1, CBX4, CBX2, RING1A, RING1B, TUBULIN, SNF2H, PCGF4 & Hela & Levine, 2002 \\
\hline $\mathrm{M} 33 / \mathrm{Cbx} 2$ & $6 \times$ His + FLAG & PHC3, PHC2, PHC1, CBX4, CBX2, RING1A, RING1B, TUBULIN, SNF2H, PCGF4 & Hela & Levine, 2002 \\
\hline РС3/CBX8 & $F L A G+M y c$ & PHC1, PHC2, PHC3, RING1A, RING1B, WDR68, CK2, PCGF1, CBX8 & Hela & Dietrich, 2007 \\
\hline MEL18/PCGF2 & $\mathrm{SBP}+\mathrm{CBP}$ & PHC1, PHC2, PHC3, PCGF2, RING1A, RING1B, YAF2, RYBP, CBX8 & Hela & Wiederschain, 2007 \\
\hline MEL18/PCGF2 & TAP & CBX8, RING1A, RING1B, PHC2A & 293 & Elderkin, 2007 \\
\hline BMI1/PCGF4 & $\mathrm{SBP}+\mathrm{CBP}$ & PHC1, PHC2, PHC3, PCGF2, RING1A, RING1B, RYBP, CBX8, CBX2 & Hela & Wiederschain, 2007 \\
\hline BCOR & $F L A G+C B P$ & BCOR, FBXL10, HSP70, RING1A, RING1B, RYBP, PCGF1, SKP1 & Hela, 293T & Gearhart, 2006 \\
\hline NSPC1/PCGF1 & $F L A G+C B P$ & BCOR, FBXL10, HSP70, RING1A, RING1B, RYBP, PCGF1, SKP1 & Hela, 293T & Gearhart, 2006 \\
\hline E2F6 & FLAG, HA & MGA, MAX, E2F6, DP1, L3MBTL2, PCGF6, RING1A, RING1B, HP1Y, YAF2 & Hela & Ogawa, 2002 \\
\hline WDR5 & FLAG & $\begin{array}{l}\text { MGA, CHD8, MLL, LAS1L, PRPF31, C18ORF37, MOF, MCRS, TAF1, TAF4, PHF20, HCF1, TEX10, ASH2L, HSP70, } \\
\text { RBBP5, SENP3, WDR5, RING1B, E2F6, TAF9, MAX }\end{array}$ & Hela & Dou, 2005 \\
\hline Ring1B/Rnf2 & Biotin & $\begin{array}{l}\text { Phc1, Phc3, Snf2h, Cbx4, Shcm1, Hsp7c, Pcgf4, Pcgf2, Ring1A, Ring1B, Cbx8, Mga, Ehmt1, L3mbtl2, DP1, E2f6, } \\
\text { Pcgf6, Yaf2, Myn, Cbx3, mAM, BcoR, Fbxl10, Setdb1, Usp7, Lsd1, matrin3, Lcp1, kaiso, Xrcc5, Mllt1, Mta1, IRA1, } \\
\text { Parafibromin, Cbx6, Rbbp4, Rbbp7, Ctbp2, Ck2a1, Wdr68, Ck2a2, Wdr5, Pcgf3, Pcgf1, Ck2b, Pcgf5, Cbx7, Skp1 }\end{array}$ & MEL & Sánchez, 2007 \\
\hline SMCX/KDM5C & $F L A G+H A$ & JARID1C, MGA, NCOR1, REST, G9A, L3MBTL2, HDAC1, HDAC2, DP1, RING1A, RING1B, E2F6, HP1G, MAX & Hela & Tahiliani, 2007 \\
\hline MLLT1/ENL & FLAG & AF5q31, AF4, BCOR, CBX8, LAF4, DOT1L, CYCT2, ENL, HSP70, p52RO, TUB6, RING1, PIP5K2C, CDK9 & 293 & Mueller, 2007 \\
\hline
\end{tabular}


Rbbp, Rbbp7 and other Wdr proteins (Sánchez, 2007).

One of the complexes found to contain Ring1B, isolated through the purification of Wdr5-associated proteins (Dou, 2005), has a clear role in transcriptional activation because the H3K4 methyltransferase Mll1and MOF, a H4K16 histone acetyl transferase (HAT), are found among its subunits. In another complex (Mueller, 2007), RING1A is associated to subunits such as DOT1L, a histone methyl transferase for $\mathrm{H} 3 \mathrm{~K} 79$, a mark found on coding parts of transcriptional units, and to $\mathrm{pTEFb}$, a kinase for RNA polymerase II (RNA pol II), that are involved in transcription elongation. These observations suggest that roles of Ring1 proteins in transcriptional regulation may not necessarily be restricted to silencing functions.

\section{Ring1 protein-dependent monoubiquitylation of his- tone H2A}

About $5-15 \%$ of all histone $\mathrm{H} 2 \mathrm{~A}$ in mammalian cells is modified by monoubiquitylation (Matsui, 1979; Goldknopf, 1980) at lysine 119 , in the $\mathrm{C}$ terminal end of the protein (Nickel, 1989). This bulky modification occurs at the proximity of the binding site of linker histones, facilitating the association of histone $\mathrm{H} 1$ to nucleosomes (Jason, 2005). During the isolation of a complex (es) responsible for $\mathrm{H} 2 \mathrm{~A}$ monoubiquitilation, a PRC1-like (PRC1I) complex, consisting of RING1A, RING1B, BMI1/PCGF4 and $\mathrm{PH} 2 / \mathrm{PHC} 2$ was identified (Wang, 2004). H2A ubiquitylation was determined in an'in vitro assay with added ubiquitin and E1 (ubiquitin-activating) and E2 (activated ubiquitin transfer) ligases and nucleosomes as a substrate. In the reaction, ubiquitin is activated, in an ATP-dependent reaction by the E1component and subsequently conjugated to the E2 component. Finally, transference of ubiquitin to a lysine residue on the substrate is mediated by the E3 ubiquitin ligase (Kerscher, 2006). Ring1B is the only PRC1I component with E3 ubiquitin ligase activity (Wang, 2004). Mass spectrometry analysis demonstrates that in vitro ubiquitylation of $\mathrm{H} 2 \mathrm{~A}$ occurs at lysine 119 , just as the in vivo modified histone H2A. Mutagenic analysis of Ring1B demonstrates that the ubiquitin E3 ligase activity depends on an intact RING finger (Wang, 2004). In agreement with this, recombinant Drosophila Sce/dRING was found to be active in this assay, whereas the form encoded by the $S c e^{32 M}$ allele, a variant protein with a mutation in the RING finger [R65C, (Fritsch, 2003)], was not. Recently, at least two other histone $\mathrm{H} 2 \mathrm{~A}$ monoubiquitin E3 ligases have been identified, Rnf8 (Mailand, 2007) and hRUL138 (Zhou, 2008). However, Ring1B appears as the major E3 ubiquitin ligase for $\mathrm{H} 2 \mathrm{~A}$ in mammalian cells, as deduced from the magnitude of the decrease of total $\mathrm{H} 2 \mathrm{AUb}$ in cells with reduced levels of Ring1B (de Napoles, 2004; Wang, 2004). Moreover, loss of H2AK119Ub1 marks at regulatory regions of a Hox gene and its derepression in cells with reduced Ring1B levels, links Ring1Bdependent $\mathrm{H} 2 \mathrm{~A}$ monoubiquitylation to transcriptional repression (Wang, 2004). Additional correlative evidence for a role of $\mathrm{H} 2 \mathrm{AUb}$ in gene repression comes from its accumulation at inactive $\mathrm{X}(\mathrm{Xi})$ chromosome of mammalian cells, a modification which is also dependent on the presence of Ring1B (de Napoles, 2004; Fang, 2004). It is worth noting that histone $\mathrm{H} 2 \mathrm{AUb}$ is detected in all multicellular organisms in which Ring1 orthologs have been identified (de Napoles, 2004). Thus plants or slime molds (Dictyostelium) show undetectable levels of $\mathrm{H} 2 \mathrm{AUb}$, whereas the very low levels detected in Caenorhabditis elegans may result from the activity of some RING finger E3 ligase not related to Ring1 proteins.

Recently, it has been found that H2A.Z, a variant histone that replaces $\mathrm{H} 2 \mathrm{~A}$ at nucleosomes in active genes and in facultative heterochromatin of mammalian cells (Farris, 2005; Barski, 2007; Gévry, 2007; Sarcinella, 2007) can also be monoubiquitylated in a Ring1B-dependent manner (Sarcinella, 2007). H2A.Z monoubiquitylation, like in $\mathrm{H} 2 \mathrm{~A}$, occurs at the $\mathrm{C}$-terminal end. H2A.ZUb1 has been found on the Xi of female cells. Unfortunately, the antibodies available do not allow to determine whether H2A.ZUb1 is found at other locations.

\section{Coactivators for Ring1-dependent histone H2A ubiquitylation}

In vitro ubiquitylation of nucleosomal histone $\mathrm{H} 2 \mathrm{~A}$ by purified, recombinant, RING1B is much less efficient than that of PRC1I or reconstituted complexes containing RING1A, RING1B, BMI1 and PC3 (Wang, 2004; Cao, 2005). This suggested that other PRC1 subunits may act as positive cofactors in the monoubiquitylation of histone $\mathrm{H} 2 \mathrm{~A}$. Indeed, $\mathrm{Bmi} 1$ was found to stimulate the ubiquitylating activity of Ring1B, either as full length proteins (Cao, 2005) or just as $\mathrm{N}$-terminal fragments of both proteins (Buchwald, 2006) providing that their RING fingers are intact $(\mathrm{Li}, 2006)$. This is not unexpected, considering that the stable association of Ring1B and Bmi1 depends on their RING fingers (Hemenway, 1998) and it is fully explained by the multiplicity of contacts between the RING fingers of the two proteins, as shown by the crystallographyc analysis of Ring1B-Bmi1 dimers (Buchwald, 2006; Li, 2006). Thus, inactivation of Bmi1 in tissue culture cells results in a decrease of global H2AUb levels and in a reduction of $\mathrm{H} 2 \mathrm{AUb}$ marks on nucleosomes at target genes such as Hoxc5 (Wei, 2006).

The in vitro $\mathrm{E} 3$ ligase activity of Ring1 $A$ appears weaker than that of Ring1B (Wang, 2004). However, this activity is also stimulated by Bmi1 to levels comparable to those attained with Ring1B-Bmi1dimers (Buchwald, 2006; Wei, 2006). Ring1A inactivation results in derepression of some Hox genes (del Mar Lorente, 2000; Cao, 2005). Although much of the global H2AUb levels are dependent on Ring1B (Wang, 2004), a contribution of Ring1A to global $\mathrm{H} 2 \mathrm{~A}$ ubiquitylation is deduced from the reduction in total $\mathrm{H} 2 \mathrm{AUb}$ levels in Ring1A-deficent fibroblasts (Cao, 2005) and from further depletion in compound Ring1A, Ring1B deficient cells (de Napoles, 2004). Additional evidence for Ring1A-dependent $\mathrm{H} 2 \mathrm{AUb}$ is the colocalization of Xist mRNA, Ring1A and H2AUb marks on the Xi chromosome of differentiating Ring1B-deficient female ES cells (Leeb, 2007).

In vitro experiments also show that $\mathrm{UbcH} 5 \mathrm{c}$ is the $\mathrm{E} 2$ ligase that specifically stimulates the ubiquitylation reaction by Ring1BBmi1 dimers (Buchwald, 2006). Despite this activation, contacts between $\mathrm{UbcH} 5 \mathrm{c}$ and RING finger proteins must be transient because no stable complex can be identified, thus making difficult the mapping of the interacting regions. However, using the structures of other E3 ubiquitin ligases (BRCA1, $\mathrm{CHIP})$ and their associated E2 ligases $(\mathrm{UbcH} 7, \mathrm{UbcH} 13)$ as a reference, it was inferred that $\mathrm{UbcH} 5 \mathrm{c}$ would contact the two $\mathrm{Zn}^{2+}$-binding loops of Ring1B, which are accessible in the Ring1B-Bmi1 dimer (Buchwald, 2006; Li, 2006). In agreement 

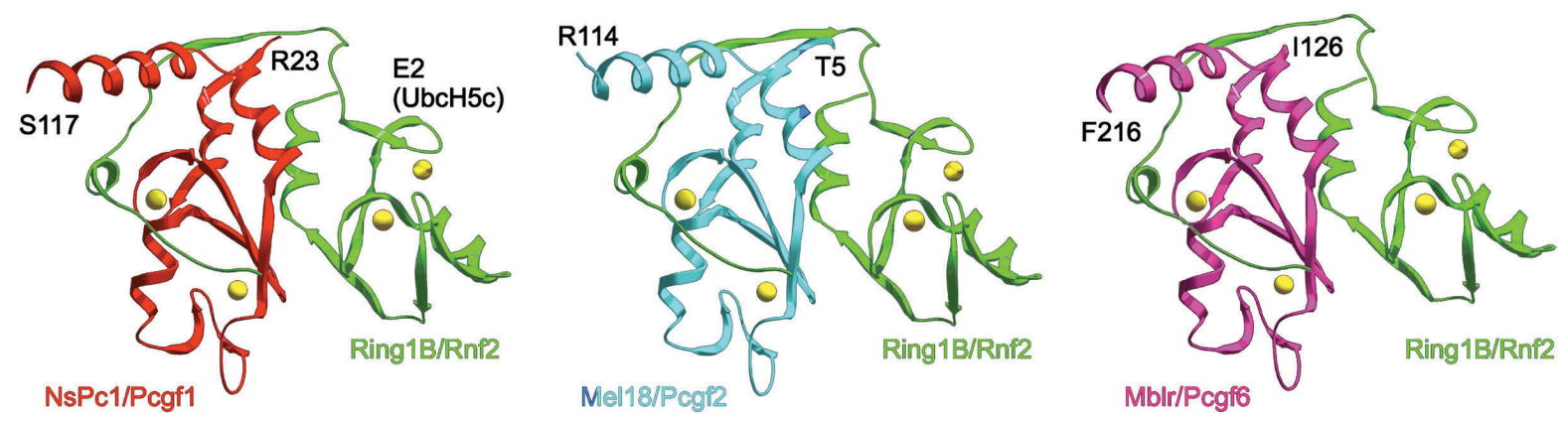

Fig. 3. Models of the associations of murine Ring1B and Pcgfs. Three-dimensional models were built using a knowledge-based protein modeling method based on the given pairwise sequence-template alignments with the $A$-chain of the 2.5 - $\AA$-resolution $X$-ray crystallographic structure of human BMI-1-RING1B polycomb complex as the template [PDB code 2hOd, (Li, 2006)]. Nest, a module of the Jackal software package (Petrey, 2003) was used to build the final structures of the models. Computations were carried out using a SGI Octane workstation. Ribbon representation of backbones in green (Ring1B/Rnf2), red (NsPc1/Pcgf1), cyan (Mel18/Pcgf2) and purple (Mblr/Pcgf6). The Zn-atoms are displayed as VdW volumes in yellow. The Ring1B loop important for E2 ligase Ubc5Hc association is shown. Numbers correspond to the amino acids of the various Pcgfs proteins included in the models.

with this notion, the mutation of a residue in this region of Ring1B, I50 abolishes its E3 ligase activity, eventhough the overall RING finger structure is not compromised (Buchwald, 2006).

If Ring1B (and likely Ring1A) provide docking surfaces for the E2 ligase, which is the mechanism for the activating role of Bmi1? In vitro evidence suggests that Ring1B, which is degraded by an unknown E3 ubiquitin ligase (Ben-Saadon, 2006), is stabilized by Bmi1. At the same time, Bmi1 modulates Ring1B self-ubiquitylation (Buchwald, 2006), an activity which is needed for efficient $\mathrm{H} 2 \mathrm{~A}$ ubiquitylation (Ben-Saadon, 2006). It has also been proposed that Bmi1 facilitates association to the substrate, nucleosomal histone $\mathrm{H} 2 \mathrm{~A}$, although no direct experimental evidence supports this suggestion (Buchwald, 2006; Li, 2006).

In summary, structural and functional analysis of the Ring1BBmi1 pair explains the essential role of RING fingers in H2A ubiquitylation in at least three aspects: (i) they are needed for the mutual stabilization and association of RING finger proteins to each other, (ii) the docking of the E2 ligase, and (iii) modulation of the ubiquitylation process itself. An additional interesting observation deduced from these studies is the wrapping of Bmi1 by $\mathrm{N}$-terminal sequences of Ring1B. Together with the fact that amino acids 92-190, C-terminal to the RING finger, contain the lysines involved in Ring1B polyubiquitylation (BenSaadon, 2006), it may explain the high sequence conservation of the N-terminal domain of Ring 1 proteins. It appears as if a very specific module, that includes the RING finger and adyacent sequences, has been selected during evolution to ensure regulated histone $\mathrm{H} 2 \mathrm{~A}$ ubiquitylation.

\section{Heterogeneity of Ring1-Pcgf H2A ubiquitylating com- plexes}

Bmi1 is one of the members of the so-called Polycomb group ring finger family (Pcgf), a term that may need to be reviewed since two other Polycomb RING finger proteins, Ring1A and Ring1B do not belong into that family. Because of structural similarity, it may have been expected that, like Bmi1, Pcgf proteins might also act as coactivators of Ring1A or Ring1B mediated H2A ubiquitylation. In fact, like Bmi1, the other Pcgf proteins, Mel18/Pcgf2, MBLR/Pcgf6, Nspc1/Pcgf1, Pcgf5 and Pcgf3 have all been found in complexes that contain Ring1 $A$ and Ring1B (Table 3). Of these, the BCOR-FBXL10 complex, which contains NSPC1/PCGF1, has been found to stimulate in vitro ubiquitylation of nucleosomal H2A (Gearhart, 2006). Since Nspc1/Pcgf1 enhances Ring1B ability to ubiquitylate H2A in vivo (Sánchez, 2007) it is likely that it acts as a coactivator similar to Bmi1. A first study on Mel18/Pcgf2 reported its inability to cooperate with Ring1B in $\mathrm{H} 2 \mathrm{~A}$ modification (Cao, 2005). However, a contrasting report indicates that phosphorylated, but not unphosphorylated, Mel18/Pcgf2 stimulates Ring1B E3 ligase activity on nucleosomal substrates (Elderkin, 2007). In agreement with this observation, ectopic expression of Mel18 in Bmi1-deficient ES cells represses some of the targets upregulated in the absence of Bmi1 (Elderkin, 2007), suggesting a functional redundancy between these Pcgf proteins. As phosphorylated Mel18 associates preferentially to the chromatin fraction of tissue culture cells it has been suggested that recruitment of the ubiquitylating complex to nucleosomes is regulated through a phosphorylation dependent event on the E3 ligase cofactor (Elderkin, 2007). However, a more direct approach, perhaps by using cells that express a nonphosphorylatable form of Mel18, is needed to support this regulatory switch.

Remarkably, the available evidence suggests that Ring1B and Ring1A are paired with only one of the various Pcgfs in each of the complexes identified. For instance, BCOR-FBXL10 complexes contain only NSPC1/PCGF1 (Gearhart, 2006; Sánchez, 2007), and E2F6 complexes contain only MBLR/ PCGF6 (Ogawa, 2002). Also, the isolation of complexes using a tag approach with BMI1 or MEL18 does not result in the copurification of BMI1 and MEL18 or any other PCGF member (Wiederschain, 2007). Fig. 3 shows a modelization of predicted Ring1B-Pcgf pairs, based on the Ring1B-Bmi1 structure. Given the high sequence conservation between Pcgf RING fingers, it is not unexpected that the predicted structures for these Ring1BPcgf pairs overlaps that of Ring1B-Bmi1. Identical structures can also be modelled for Ring1A-Pcgf pairs (not shown). However, Pcgf protein sequences outside the RING finger and 
adjacent sequences diverge considerably, making it possible that the different Ring1-Pcgf pairs are functionally diverse.

\section{Recruiting Ring1A, Ring1B-containing complexes to their gene targets}

Drosophila Hox genes were the first known targets of PcG products. Localization studies on Drosophila polytene chromosomes showed binding of PcG proteins, including Sce/dRING, to $>100$ cytological bands (Zink, 1989; Gorfinkiel, 2004), suggesting that the number of targets was larger than anticipated. Recent improvements in methods for the analysis of immunoprecipitated chromatin on a genome-wide scale have confirmed this suggestion both in mammalian and Drosophila cells (Boyer, 2006; Bracken, 2006; Lee, 2006; Nègre, 2006; Schwartz, 2006; Tolhuis, 2006).

Ring1B genome-wide binding sites are only known for murine and human ES cells (Boyer, 2006; Endoh, 2008; Ku, 2008). The analysis, both by ChIP-chip and ChIP-seq (immunoprecipitaded DNA identified by hibrydization to tiled arrays of oligonucleotides or by sequencing, respectively) identifies between 1000-1300 sites corresponding to annotated promoters. Most of these sites are also bound by other PcG proteins [eed, Suz12, Ezh2 and Phc1 (Boyer, 2006; Pasini, 2007; Ku, 2008)].Ring1B binding sites correlate with a repressive function on loci that for the most part encode transcription factors and signaling molecules with known roles in major developmental processes. Similar results were obtained for CBX8, EZH2 and SUZ12 in human embryonic fibroblasts (Bracken, 2006). Similar mapping analysis of H3K27me3 marks shows co-occupancy with most sites bound by PcG proteins (Boyer, 2006; Bracken, 2006). Interestingly, however, Ring1B binding sites in ES cells corresponds only to half of H3K27me3 domains, characterized by their large size and when on $\mathrm{CpG}$ islands, these are among the longest (Ku, 2008). These genomic domains are conserved between mouse and human ES cells. On the other hand, H2AK119Ub1 marks, are known only for a handful of PcG targets (Stock, 2007). It is worth noting that the study of DNA sequences bound or modified by mammalian PcG proteins, has failed to identify regions similar to the so-called Polycomb response elements (PRE) of Drosophila. PREs are DNA sequences with multiple binding sites for DNA binding proteins able to recruit PcG complexes (Ringrose, 2007). In contrast to PcG proteins, none of these DNA binding proteins, except for YY1, the homolog of Pho and Phol, have vertebrate homologs (Müller, 2006). Whether this implies a fundamental difference between insects and vertebrates in PcG complex(es) recruiting to their targets is not known.

Expression analysis of Ring1B-deficient ES cells shows that most of the Ring1B targets identified in ChIP experiments are upregulated (Leeb, 2007; Endoh, 2008). Inactivation of PRC2 components eed or Suz12 in ES cells leads to a similar observation (Boyer, 2006; Lee, 2006; Pasini, 2007). These results are consistent with the current paradigm for $\mathrm{PRC} 1$ recruiting to targets, initially based on the observation that in Drosophila the occupancy of H2AK1 19Ub1-containing nucleosomes at PcG gene targets was dependent on the activity of PRC2 component $E(Z)$ (Wang, 2004). In this paradigm, chromodomain-containing subunits in PRC1 complexes (for instance, M33/Cbx2, Pc3/Cbx8, $\mathrm{Pc} 2 / \mathrm{Cbx} 4$, etc), which are known to associate preferentially to $\mathrm{H} 3$ histone tail peptides trimethylated at the lysine 27 (Fischle, 2003; Min, 2003; Bernstein, 2006b) would act as "readers" of H3K27me3 modified nucleosomes, and contribute to its stable association to regulatory regions. In line with this prediction, an enhancement of H3K27me3 levels at promoters of selected Hox genes, after inactivation of the H3K27 demethylase UTX/KDM6A, is accompanied by increases in RING1A and BMI1 occupancy and also of increased H2AK119Ub1 marks (Lee, 2007). However, this model of chromatin modification needs to accommodate evidence for a reciprocal activity, by which $\mathrm{PRC} 2$ recruitment is facilitated or stabilizated by PRC1, as suggested by the decrease in nucleosomal occupancy and H3K27me3 marks at PcG targets in Ring1A and Ring1B-deficient ES cells (Endoh, 2008).

Despite the prevalence of the histone H3K27me3-directed recruitment of Ring1A-Ring1B complexes, there are examples in which their recruiting is independent of such a histone-reading mechanism. For instance, Ring1B association to the Xi chromosome in female ES cells that are deficient in eed, occurs in the absence of H3K27me3 marks (Schoeftner, 2006). Another example is the localization of maternal Ring1B and other PRC1 subunits to paternal heterochromatin of preimplantation Ezh2-mouse embryos which lack H3K27me3 marks (Puschendorf, 2008). Whereas these heterochromatic regions may represent specific situations, they show the feasibility of recruiting mechanisms other than $\mathrm{H} 3 \mathrm{~K} 27 \mathrm{me} 3$ binding. One of the possibilities is through binding to $\mathrm{RNA}$, as described for a $\mathrm{Zn}^{2+}$-binding domain in Polyhomeotic PRC1 subunits, a motif initially identified in the product of SOP-2, a Hox gene regulator in C. elegans (Zhang, 2004).

\section{Mechanisms of transcriptional repression of Ring1A, Ring1B targets}

PcG-mediated represses transcription through one or more mechanisms, possibly in a coordinated manner, still poorly characterized [reviewed in (Francis, 2001a; Schuettengruber, 2007)]. Three major categories of mechanisms appear involved: (i) nuclear organization, (ii) chromatin remodeling and (iii) modulation of the transcriptional machinery.

Control of Hox clusters in Drosophila involves regulation of higher-order chromatin structure and nuclear organization (Bantignies, 2003; Lanzuolo, 2007). Related mechanisms in mammals also play important roles in Hox gene expression or in loci located in PcG regulated clusters (Mager et al., 2003; Chambeyron, 2004; Murrell, 2004). Biochemical and structural analysis provides evidence for PRC1 and PRC2 complexes facilitating the in vitro compaction of nucleosomal arrays (Francis, 2004; Margueron, 2008). Recently, chromatin structure studies suggest that PcG repressed loci adopt a complex multi-loop conformation whose topological structure depends, at least, on PRC2 subunits (Tiwari, 2008). It is likely that protein-protein interactions among subunits of PcG complexes play a role in the organization and stabilization of these higher-order structures, rather than interfering with the accessibility of activators, which are known to interact with their binding sites even in mitotic chromatin (Chen, 2005). PRC1 has also been shown to interfere in vitro with the activity of chromatin remodelers (Shao, 1999), which may be of relevance in switching between inactive/active states. However, ectopic expression of hSNF5, a subunit of the 
SWI/SNF chromatin-remodeling complex, leads to derepression coupled to eviction of PcG complexes from repressed loci (Kia, 2008). As for the transcriptional machinery itself, studies on PcGmediated repression of a gene model in Drosophila have shown that in the repressed state, RNA pol II cannot initiate transcription (Dellino, 2004). Additional correlative evidence for a role of PcG in transcription initiation is the occupancy of silenced promoters by the TATA binding protein (Breiling, 2001) and the appearance of subunits of the transcription initiation machinery in PRC1 complexes from Drosophila embryos (Saurin, 2001). Recently, histone Ring1-dependent H2A monoubiquitylation has been linked to the regulation of RNA pol II at transcription initiation sites (Stock, 2007).

\section{H2A monoubiquitylation and transcriptional repres- sion}

RNA Pol II associates to most promoters, regardless of the levels of transcriptional output (Guenther, 2007). In ES cells, promoters of PcG-repressed targets have a form of RNA Pol II that is phosphorylated at Serine 5 [Ser5P (Stock, 2007)]. Another feature of promoter proximal regions of PcG targets in ES cells is their co-occupancy by both H3K4me3 and H3K27me3 marks (Azuara, 2006; Bernstein, 2006a). Chromatin regions that contain these functionally opposed histone marks are termed bivalent domains and were first thought of as specialized chromatin structures associated to the maintenance of silent genes in a transcription-ready state. Indeed, many of these bivalent structures are resolved during differentiation of ES cells, so that active genes keep the H3K4me3 marks and silent ones keep H3K27me3 or lose both marks (Mikkelsen, 2007; Mohn, 2008; Cui, 2009). Recent genome-wide chromatin immunoprecipitation (ChIP) studies in Drosophila, show that RNA pol II binds at the transcription initiation site of a large number of silent, developmentally regulated genes (Muse, 2007; Zeitlinger, 2007), suggesting that stalling RNA Pol II is an important regulatory step for genes that have to accommodate dynamic transcriptional responses to developmental cues.

In this context it is highly relevant that Ring1 proteins play a decisive role in maintaining stalled RNA pol II at promoters of bivalent domains of ES cells (Stock, 2007). Thus, the inactivation of Ring1 A and Ring1B results in the sequential loss of H2AK119Ub1 at promoters, the release of poised RNA pol II and gene derepression. The mechanistic link between $\mathrm{H} 2 \mathrm{~A}$ modification and transcription initiation is not known, but conformational changes in RNA pol II upon loss of Ring1A-Ring1B (Stock, 2007) suggests postranslational modification (s) or reorganization of protein complex (es). In the converse situation, the stabilization of $\mathrm{H} 2 \mathrm{AK} 119 \mathrm{Ub} 1$ marks resulting from the inactivation of a H2A ubiquitin protease, concurs with a decrease in RNA pol II Ser5P occupancy at the promoter and a reduction of two transcription elongation marks, RNA pol II Ser2P and H3K36me3 (Zhou, 2008). Additional evidence supporting a role for $\mathrm{H} 2 \mathrm{~A}$ monoubiquitylation in transcription initiation comes from in vitro studies in which transcription initiation, but not elongation, occurs when the nucleosomal templates are assembled with H2AK119Ub1 (Nakagawa, 2008). These experiments also showed that H2AK119Ub1 interferes with the dimethylation and trimethylation of histone $\mathrm{H} 3 \mathrm{~K} 4$, an observation that is in agree- ment with the enhanced occupancy of $\mathrm{H} 3 \mathrm{~K} 4 \mathrm{me} 3$ marks at promoters of Ring1A and Ring1B-deficient ES cells (Endoh, 2008). The mechanism of transcriptional repression through H2AK119Ub1, however, may differ depending on the E3 ligase involved or the regulatory context. Thus, repression in macrophages of a chemokine gene mediated by the E3 ligase 2A-HUB/ hRUL138 occurs with inhibition of transcriptional elongation, perhaps because the E3 ligase is recruited as part of a N-CoR/ HDAC1/3 complex (Zhou, 2008). It would be interesting to investigate whether the repression of the bivalent domains identified in differentiated cells (Azuara, 2006; Barski, 2007; Mikkelsen, 2007; Pan, 2007; Roh, 2006; Zhao, 2007) depends on Ring1 proteins or on another E3 ligase (s). The fact that linker histone $\mathrm{H} 1$ association is facilitated by H2AK119Ub1 (Jason, 2005) may also contribute to transcriptional repression, and one of the consequences of $\mathrm{H} 2 \mathrm{~A}$ deubiquitylation is the phosphorylation and release of histone $\mathrm{H} 1$ from nucleosomes (Zhu, 2007).

\section{Reversal of histone H2A monoubiquitylation and gene activation}

A regulatory step in transcriptional control through chromatin structure is the reversal of postranslational marks. In general, histone modifications can be reverted either by nucleosome eviction or through the action of enzymes that remove the covalent modification. Which mechanism is used may determine either a long-term or short-term outcome for a given modification. Up to now, five proteases have been shown to remove ubiquitin moieties from histone H2A. Most, USP3 (Nicassio, 2007), USP16 (Joo, 2007), USP21 (Nakagawa, 2008) and USP22 (Zhang, 2008; Zhao, 2008), are members of the cysteine family of proteases, which use a carboxyl-terminal hydrolase-like $(\mathrm{UCH})$ zinc finger as a catalytic domain. The remaining ubiquitinase, 2A-DUB/MYSM1 (Zhu, 2007), belongs to the family of metalloproteases that have a JAMM/MPN ${ }^{+}$motif as catalytic domain. USP3 and USP22 are not H2A-specific and also deubiquitylate H2B. Since mammalian genomes encode a large number of deubiqutinases (Nijman, 2005), it is possible that additional $\mathrm{H} 2 \mathrm{~A}$ deubiquitinases will be found. It is not clear, however, whether all of them will be involved in gene expression control. For instance, whereas USP16 inactivation leads to upregulation of some Hox genes (Joo, 2007), it also causes defective progression through the cell cycle of mutant cells (Joo et al., 2007). It is known that H2AUb (and H2BUb) loses its ubiquitin moiety during mitotic chromatin condensation, followed by subsequent reubiquitylation in early anaphase (Matsui, 1979; Goldknopf, 1980). This exchange of ubiquitin on H2A is required for appropriate cell cycle progression because in the absence of deubiquitylation, Aurora B, the kinase that phosphorylates Serine 10 of histone $\mathrm{H} 3$ and that is required for mitotic chromatin condensation, does not associate to nucleosomes compromising adequate mitotic condensation (Joo, 2007). Another reason for cell cycle delays associated to $\mathrm{H} 2 \mathrm{~A}$ deubiquitylation is the activation of the DNA damage response that occurs during the inactivation of USP3 (Nicassio, 2007).

In contrast, 2A-DUB/MYSM, a H2A ubiquitin protease with histone (SANT) and DNA binding domains (SWIRM) appears closely related to gene expressioncontrol. Identified as an activator of the hormone inducible gene PSA, it is part of a complex that contains the PCAF (p300/CBP associated factor) histone acetyl 
transferase (Zhu, 2007). Treatment of tissue culture cells with HAT inhibitors (which results in hyperacetylated nucleosomes) enhances the deubiquitinating activity of 2A-DUB/MYSM1. The finding that androgen and estrogen-dependent gene targets, but not those dependent on retinoic acid or thyroid hormone, are affected by the downregulation of 2A-DUB/MYSM suggests that derepression through $\mathrm{H} 2 \mathrm{~A}$ deubiquitylation is a process regulated by specific recruiting of HAT-containing complexes (Zhu, 2007). Figure 4 shows a simplified view of reversible modifications at nucleosomes of bivalent genes. Here, recruitment of a hypothetical complex containing a H2A ubiquitin protease(s) and a HAT would cooperate with another complex involved in H3K27 demethylation (Cho, 2007; De Santa, 2007; Lee, 2007). The activity of SAGA complexes, modular assemblies involved in the regulated access of general transcription factors to DNA mediated by histone acetylation, provide additional support for gene activation through coordinated H2A deubiquitylation, by USP22, and histone acetylation (Zhao, 2008). Conversely recruiting of PRC2, which may bring in a HDAC, through its Eed component (van der Vlag, 1999), would facilitate PRC1 association and RNA pol II stalling. In this respect, dRAF, a Drosophila complex related to the mammalian Ring1Fbxl10 complex (Gearhardt, 2006; Sánchez, 2007) has been shown to promote $\mathrm{H} 2 \mathrm{~A}$ ubiquitylation and $\mathrm{H} 3 \mathrm{~K} 36 \mathrm{me} 2$ demethylation in a coordinated fashion (Lagarou, 2008).

Whether any of these proteases is specifically involved in the removal of Ring1-mediated H2AUb is not known. Ring1A-Ring1B are responsible for most $\mathrm{H} 2 \mathrm{AUb}$ in the genome. However, it is possible that only a subset of the nucleosomes thus modified localize to promoters and other cis-acting control regions. For instance, Ring1B-dependent $\mathrm{H} 2 \mathrm{AUb}$ has been found to occur also during the DNA damage response induced by UV radiation (Bergink, 2006).

\section{Functional activity of Ring1 proteins}

Being general transcriptional regulators, Ring1 proteins activity impacts on a multiplicity of processes both during embryonic

Poised RNA pol II

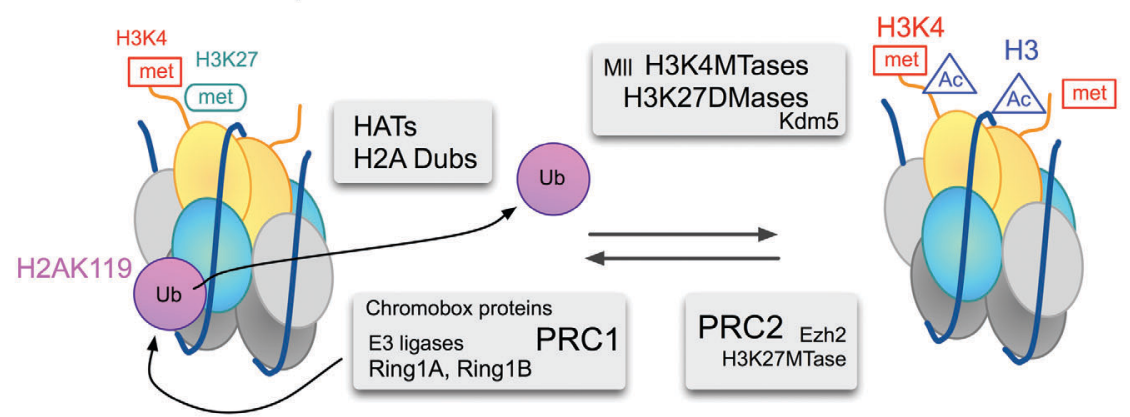

Fig. 4. Model for the reversible switch of transcriptional states at a bivalent promoter. In the inactive state, the E3 ubiquitin ligase acitivity of Ring $1 A$ and Ring $1 B$ in PRC1 is needed for the maintenance of RNA pol II in a stalled, non-elongating, state. H3K27me3 marks, that depend on PRC2 contribute to stabilize PRC1 association. Recruitment of transcription activating complexes, perhaps through transcription factors bound to DNA sites uncovered by chromatin remodelers, involve coordinated histone modifying activities. Histone acetylation and H2A deubiquitylation, may be trigger modifications of RNA pol II. Demethylation of H3K27 and further methylation of H3K4 would help recruiting TFIID (Vermeulen, 2007) and other componentes of the transcription initiation machinery, thus sustaining transcription. development and in adult life. Ring1 proteins, as part of PRC1 or of other complexes, contribute to the execution of genetic programs that determine the maintenance of stem cells and the ordered differentiation of their progeny. This includes not only the regulation of developmentally relevant genes, but also repression of heterochromatic structures and control of cell proliferation. Perhaps not surprisingly, some cancer cells show deregulated expression of Ring1 proteins.

\section{During development}

Constitutive inactivation of Ring1B in mice leads to embryo death in uterus, around gastrulation time (Voncken, 2003). The mechanisms underlying this embryonic lethality are not known. In contrast, mice deficient in Ring1A are fertile and without an overt phenotype (del Mar Lorente, 2000). Why would Ring1B compensate for the loss of Ring1A and not the other way around? It is possible that the two paralogs are functionally distinct, despite of their structural similarity; alternatively, their expression patterns may not be overlapping. For instance, if Ring1A levels at early stages of development were too low, it would not complement a critical function carried out by Ring1B.

Loss of function of either of the two proteins alters the axial skeleton of mutant mice (del Mar Lorente, 2000; Suzuki, 2002). Thy Ring1A-deficient fetuses show anterior homeotic served in other PcG mutant mice [with the exception of YY1, Lorente, 2006)] is not known. The minor alterations of Hox gene expression observed in midgestation Ring1A-deficient embryos 2000), although the effect of transient deregulation of Hox gene expression during earlier embryogenesis cannot be ruled out. The impact of Ring1B on antero-posterior axis specification has been deduced from the genetic interaction between a Ring1B whereby double mutant mice showed higher penetrance and expressivity of $\mathrm{Mel}^{\mathrm{N}} / \mathrm{\text {induced }}$ posterior transformations. Genetic interactions have also been observed in Bmi1-deficient mice that are also heterozygous mice for a null Ring1B allele (Voncken, 2003). An example of the wide range of processes affected by PcG products is illustrated by the abnormalities in the anterior eye of Ring1Adeficient mice, a defect enhanced by a reduction of YY1 dosage (Lorente, 2006).

\section{Maintenance of stem cells}

PcG act as regulators of embryonic and adult stem cell maintenance (Valk-Lingbeek, 2004). For instance, in ES cells, Ring1 proteins act as a repressors of a large number of developmental regulators (Leeb, 2007; Endoh, 2008).

Gene expression patterns of Ring1A-deficient ES cells are little altered, compared to those associated to Ring1B deficiency (Endoh, 2008), a situation reminiscent to the stronger phenotype of Ring1B mutant embryos compared to that of embryos lacking Ring1A (del 
Mar Lorente, 2000). Whereas these observations suggest functional differences between Ring1 proteins, double mutant Ring1A and Ring1B ES cells show enhanced gene derepression and eventually cessation of cell proliferation (Endoh, 2008), indicating a convergence of regulatory pathways. In ES cells, Ring1 proteins and other PcG products, play their repressive functions under the control of the selfmaintained network of transcriptional factors that are mainly orchestrated by Oct3/4, Nanog (Lee, 2006; Endoh, 2008). When, in response to extracellular signals, the program for pluripotency gives in to new transcriptional programs, a reordering of epigenetic marks takes place. For instance, upregulation of GATA6, an effector of differentiation towards extraembryonic endoderm, results in dissociation of Ring1B, and other PcG products, from their former targets at undifferentiated ES cells (Endoh, 2008). Therefore, at least in ES cells, Ring1 proteins act as a part of a set of instructed epigenetic regulators that prevent inappropriated differentiation, illustrating intertwined cooperation of genetic and epigenetic mechanisms to ensure pluripotency (Niwa, 2007). The premature neuronal differentiation of Ring1Bdeficient fetal neural stem cells is further evidence of the contribution of PcG products to stem cell self-renewal by preventing their differentiation. In addition, the enhanced neuronal diffferentiation and reduced gliogenesis of Ring1B mutant mice (Román-Trufero, 2009) suggest a role for PcG in the temporal specification of developing neural progenitors. In contrast, Ring1B inactivation in adult stem cells and primitive progenitors of the hematopoietic compartment leads to proliferative alterations, rather than to differentiation defects (Calés, 2008). Although a detailed study on the stem cell function of Ring1B-deficient HSC is lacking, the results contrast with those derived from the study of Bmi1deficient mice (Lessard, 2003; Park, 2003). Whether this is a reflection of redundant Ring1B function in HSCs or of differences in regulatory pathways affected by the mutations remains to be established.

\section{Functions in heterochromatin}

In mammals, the imbalance of gene dosage for genes on the $X$ chromosome (two in females, one in males) is functionally equalized through the inactivation of one of the two $X$ chromosomes in females. The inactivation process is triggered by the transcription of the Xist gene on the to-be silenced $\mathrm{X}$ chromosome [reviewed in (Heard, 2006)]. Ring1A and Ring1B, together with other subunits from PRC1 and PRC2 complexes accumulate on the Xi chromosome of female mammalian cells. Accumulation of PcG products and colocalization with H2AUb and H3K27me3 marks occurs in both imprinted and randomly inactivated $\mathrm{Xi}$ (Cao, 2004; de Napoles, 2004). As expected, the PRC2 component eed is needed for the appearance of $\mathrm{H} 3 \mathrm{~K} 27 \mathrm{me} 3$ marks and the accumulation of PRC1 subunits Phc1 and Phc2 on the Xi (Plath, 2003; Silva, 2003; Plath, 2004). However, accumulation of Ring1B was found independent of both eed and H3K27me3 (Schoeftner, 2006). Inactivation of Ring1B in undifferentiated ES cells leads to the loss of H2AUb marks on the Xi (de Napoles, 2004; Leeb, 2007). Upon differentiation, Ring1B-deficient cells regain $\mathrm{H} 2 \mathrm{AUb}$ marks on the Xi, possibly due to upregulation of Ring1A (Leeb et al., 2007). Together, these observations suggest that PcG in general, and Ring1 $A$ and Ring1B in particular, are involved in the initiation of the silencing of the Xi. However, beyond this correla- tive evidence, the analysis of Ring1B-deficient ES cells has shown that neither initiation of Xist-induced Xi silencing, nor maintenance of gene repression of loci on the $\mathrm{Xi}$ depends on Ring1B (Leeb, 2007). It is possible that whereas Ring1B is required for repression of developmental regulators, maintenance of a silenced $\mathrm{Xi}$ relies on a multiplicity of repressing mechanisms. In contrast, targeting of Ring1B and PRC1 (maternally provided) to paternal heterochromatin in the zygote is accompanied by active repression, as suggested by the enhanced transcription of pericentric major satellite sequences in zygotes depleted from both embryonic and maternal Ring1B (Puschendorf, 2008). Since parentally defined formation of heterochromatic structures is over at the end of the 8-cell stage (Puschendorf, 2008), and heterozygous Ring1B mothers provide Ring1B to the zygote, it appears unlikely that a role as repressor of paternal heterochromatin has much of an impact on the developmental arrest of gastrulating Ring1B null embryos.

\section{Cell homeostasis and cancer}

The involvement of PcG products in cancer may occur both at the phase of the metastatic expansion of tumor cells and, perhaps, at the early stages of the generation of tumor stem cells. A central mechanism for cell expansion is the inactivation of the Ink4a locus, a well known tumor suppressor that encodes two powerful inhibitors of cell cycle progression, $\mathrm{p} 16^{\text {Ink4a }}$ and also p19Arf, a negative regulator of $\mathrm{p53}$, a major promoter of apoptosis (Gil, 2006). Both products derive from transcripts initiated at independent promoters, although they share exons that are translated in different reading frames. The fact that Ring1B specifically represses $p 16$ Ink4a (Voncken, 2003; Calés, 2008) may explain, at least in part, the finding of Ring1B among a reduced set of 11 genes (expression signature) that identifies human tumors with a bad prognosis (Glinsky, 2005). Certainly, Ring1B is found overexpressed in germinal-centre derived lymphomas (large Bcell lymphoma, Hodgkin's lymphoma) and in gastric and colon tumors (Sánchez-Beato, 2006). Ring1A is also overexpressed in lymphomas (Dukers, 2004; Raaphorst, 2004; Sánchez-Beato, 2004) and in malignant prostate epithelia (van Leenders, 2006). Of course, such an enhanced expression in tumor cells does not allow to distinguish between a causal role in cell transformation or in the selection of Ring1-expressing cells during tumor expansion. In this regard, it is of interest to note that the ectopic expression of Ring1A in rodent fibroblasts results in transformed cells that propagate when transplanted in immunocompromised recipient mice (Satijn, 1999).

Predisposition to malignant transformation of stem cells has been linked to PcG regulation. This is based on a correlation found between sets of genes repressed by PcG in ES cells and genes epigenetically silenced in tumor cells (Schlesinger, 2006; Widschwendter, 2006; Ohm, 2007). An example is the impaired differentiation of glioblastoma initiation cells due to the Ezh2dependent repression of a Bone Morphogenetic Protein Receptor 1B (Lee, 2008). A different situation, the enhanced self-renewal of stem cells, rather than their impaired differentiation, is associated to the overexpression of Bmi1 in murine HSCs and in human mammary stem cells (Iwama, 2004; Liu, 2006). Of the Ring1 genes, there is only one report showing enhanced levels of Ring1A transcrips in human acute myeloid leukemia stem cells 
(Ishikawa, 2007), although whether they play a causal role in their malignant transformation is not known.

Upregulation of PcG products in cancer cells has been usually associated to their role as positive regulators of cell proliferation, of which the repression of the cell cycle inhibitor, $p 16^{\text {Ink4a }}$ is an example. Recently, however, it has been reported that, in the murine hematopoietic system, Ring1B acts both as promoter and as an inhibitor of cell proliferation, depending on the cell compartment. This dual activity is a consequence of the repression of positive and negative regulator of the cell cycle machinery, namely cyclin D2 and its inhibitor $\mathrm{p} 16^{\text {Ink4a }}$ (Calés, 2008). Cyclin D2 is upregulated in all Ring1B-deficient cells, whereas $p 16^{\text {Ink4a }}$ is only upregulated in the more mature precursors. In this way, Ring1B contributes to hematopoietic cell homeostasis through restraining expansion of immature progenitor cells, whose numbers are increased by two to three fold in the absence of Ring1B, and concomitantly ensuring the appropriate expansion of their maturing progeny, which is decreased in Ring1B-deficient cells. Thus, lymphomas and leukemia normally appearing in Ink4a null mice, undergo accelerated onset in compound Ring1B, Ink4a mutant mice (Calés, 2008). Ring1B-deficient progenitors show an enhanced proliferation rate, without alterations in apoptotic levels or differentiative potential. Thus, the control of expanding populations of progenitor cells links Ring1B function to the regulation of cell homeostasis. Whether this observation is specific of the hematopoietic cell compartment or a general feature of other regenerating tissues remains to be determined.

\section{Perspectives}

The E3 protein ligase activity contributing to the maintenance of stalled RNA pol II at repressed promoters is the best molecularly characterized function of Ring1proteins. However, much remain to be learned about the specific role of this histone modification and tits dependence on Ring1A and Ring1B proteins: for instance, whether $\mathrm{H} 2 \mathrm{~A}$ ubiquitylation serving transcriptional control can be separated from global genomic ubiquitylation. The elucidation of targeting mechanisms that recruit Ring1ARing1B-containing complexes is also important. This may shed light on differential use of Ring1A-Ring1B or of other E3 ubiquitin ligases to achieve $\mathrm{H} 2 \mathrm{~A}$ ubiquitylation, perhaps dependent on the stage of cell differentiation. Obtaining genomic maps of $\mathrm{H} 2 \mathrm{AUb}$ marks, and their comparison with those of other histone marks would fill a considerable gap in the current understanding of the relationship between diverse histone modifications and would provide clues about the recruiting and differential use of E3 ligases at specific loci. Regulation of the ubiquitylation process itself, in a physiological context, has been hardly explored. Finally, further research on the link between H2AUb and RNA pol II stalling, together with the removal of H2AUb marks would help deciphering the molecular mechanisms for Ring1A-Ring1B role in transcription initiation.

Whether Ring1A-Ring1B always act as E3 ubiquitin ligases for $\mathrm{H} 2 \mathrm{~A}$ in the various complexes they belong to is not known. Ring1A-Ring1B proteins may also participate in other poorly characterized functions. For instance, it is worth exploring the possibility that Ring1A-Ring1B participate in the assembly and dynamics of multiprotein complexes, as illustrated by the dependence of PRC1 stability on Ring1B. In this regard, a remaining uncertainty is that of the possible functional differences between Ring1A and Ring1B.

The study of PcG gene function has come a long way from their initial association to the control of developmental processes regulated by Hox proteins. Recent advances show that PcG gene products are involved in a wide range of regulatory settings. Answers to the above questions should help us to obtain a better understanding of the contribution of the Polycomb system of chromatin modifiers to epigenetic regulation of gene expression.

\section{Acknowledgements}

I thank Atsushi Hijikata (RIKEN RCAl, Yokohama), Salvatore D'Aniello and Jordi García-Fernández (Universidad de Barcelona) for help with protein evolutive studies; Mario García (CIB) for molecular modeling, and Carmela Calés and members of the lab are acknowledged for comments on the manuscript. Work in my lab is funded by a grant from the Education Ministry (SAF2007-06952-CO2-01) and the OncoCycle program from the Comunidad de Madrid.

\section{References}

AKASAKA, T., TAKAHASHI, N., SUZUKI, M., KOSEKI, H., BODMER, R. and KOGA $H$. (2002). MBLR, a new RING finger protein resembling mammalian Polycomb gene products, is regulated by cell cycle-dependent phosphorylation. Genes Cells 7: 835-850.

AZUARA, V., PERRY, P., SAUER, S., SPIVAKOV, M., JØRGENSEN, H.F., JOHN, R.M., GOUTI, M., CASANOVA, M., WARNES, G., MERKENSCHLAGER, M., et al. (2006) Chromatin signatures of pluripotent cell lines. Nat.Cell Biol. 8: 532538.

BANTIGNIES, F., GRIMAUD, C., LAVROV, S., GABUT, M. and CAVALLI, G. (2003). Inheritance of Polycomb-dependent chromosomal interactions in Drosophila. Genes Dev. 17: 2406-2420.

BARSKI, A., CUDDAPAH, S., CUI, K., ROH, T.Y., SCHONES, D.E., WANG, Z., WEI, G., CHEPELEV, I. and ZHAO, K. (2007). High-resolution profiling of histone methylations in the human genome Cell. 129: 823-837.

BEN-SAADON, R., ZAAROOR, D., ZIV, T. and CIECHANOVER, A. (2006). The Polycomb protein Ring1B generates self atypical mixed ubiquitin chains required for its in vitro histone $\mathrm{H} 2 \mathrm{~A}$ ligase activity. Mol. Cell 24: 701-711.

BERGINK, S., SALOMONS, F.A., HOOGSTRATEN, D., GROOTHUIS, T.A., DE WAARD, H., WU, J., YUAN, L., CITTERIO, E., HOUTSMULLER, A.B., NEEFJES, J., et al. (2006). DNA damage triggers nucleotide excision repair-dependent monoubiquitylation of histone H2A. Genes Dev. 20: 1343-1352.

BERNSTEIN, B.E., MIKKELSEN, T.S., XIE, X., KAMAL, M., HUEBERT, D.J., CUFF, J., FRY, B., MEISSNER, A., WERNIG, M., PLATH, K., et al. (2006a). A bivalent chromatin structure marks key developmental genes in embryonic stem cells. Cell. 125: 315-326.

BERNSTEIN, E., DUNCAN, E.M., MASUI, O., GIL, J., HEARD, E. and ALLIS, C.D. (2006b). Mouse polycomb proteins bind differentially to methylated histone $\mathrm{H} 3$ and RNA and are enriched in facultative heterochromatin. Mol. Cell. Biol. 26: 2560-2569.

BORDEN, K.L. (2000). RING domains: master builders of molecular scaffolds? J. Mol. Biol. 295: 1103-1112.

BOYER, L.A., PLATH, K., ZEITLINGER, J., BRAMBRINK, T., MEDEIROS, L.A., LEE, T.I., LEVINE, S.S., WERNIG, M., TAJONAR, A., RAY, M.K., et al. (2006). Polycomb complexes repress developmental regulators in murine embryonic stem cells. Nature. 441: 349-353.

BRACKEN, A.P., DIETRICH, N., PASINI, D., HANSEN, K.H. and HELIN, K. (2006). Genome-wide mapping of Polycomb target genes unravels their roles in cell fate transitions. Genes Dev. 20: 1123-1136.

BREILING, A., TURNER, B.M., BIANCHI, M.E. and ORLANDO, V. (2001). General transcription factors bind promoters repressed by Polycomb group proteins. Nature 412: 651-655.

BUCHWALD, G., VAN DER STOOP, P., WEICHENRIEDER, O., PERRAKIS, A., VAN LOHUIZEN, M. and SIXMA, T.K. (2006). Structure and E3-ligase activity 
of the Ring-Ring complex of Polycomb proteins Bmi1 and Ring1b. EMBO. J. 25: 2465-2474.

CALÉS, C., ROMÁN-TRufERO, M., PAVÓN, L., SERRANO, I., MELGAR, T., ENDOH, M., PÉREZ, C., KOSEKI, H. and VIDAL, M. (2008). Molecular and cellular biology inactivation of the Polycomb group protein Ring1B unveils an antiproliferative role in hematopoietic cell expansion and cooperation with tumorigenesis associated to Ink4a deletion. Mol. Cell. Biol. 28: 1018-1028.

CAO, R. and ZHANG, Y. (2004). The functions of E (Z)/EZH2-mediated methylation of lysine 27 in histone H3. Curr. Opin. Genet. Dev. 14: 155-164.

CAO, R., TSUKADA, Y.I. and ZHANG, Y. (2005). Role of Bmi-1 and Ring1A in H2A Ubiquitylation and Hox Gene Silencing. Mol. Cell 20: 845-854.

CAPILI, A.D., SCHULTZ, D.C., RAUSCHERIII, F.J. and BORDEN, K.L. (2001). Solution structure of the PHD domain from the KAP-1 corepressor: structural determinants for PHD, RING and LIM zinc-binding domains. EMBO. J. 20: 165177.

CHAMBEYRON, S. and BICKMORE, W.A. (2004). Chromatin decondensation and nuclear reorganization of the HoxB locus upon induction of transcription. Genes Dev. 18: 1119-1130.

CHEN, D., DUNDR, M., WANG, C., LEUNG, A., LAMOND, A., MISTELI, T. and HUANG, S. (2005). Condensed mitotic chromatin is accessible to transcription factors and chromatin structural proteins. J. Cell Biol. 168: 41-54.

CHO, Y., HONG, T., HONG, S., GUO,H., YU, H., KIM, D., GUSZCZYNSKI, T., DRESSLER, G.R., COPELAND, T.D., KALKUM, M., et al. (2007). PTIP associates with MLL3- and MLL4-containing histone $\mathrm{H} 3$ lysine 4 methyltransferase complex. J. Biol. Chem. 282: 20395-20406.

CUI K, ZANG C, ROH TY, SCHONES DE, CHILDS RW, PENG W and ZHAO, K. (2009) Chromatin signatures in multipotent human hematopoietic stem cells indicate the fate of bivalent genes during differentiation. Cell Stem Cell 4:80-93.

CZYPIONKA, A., RUIZ DE LOS PAÑOS, O.R., MATEU, M.G., BARRERA, F.N., HURTADO-GÓMEZ, E., GÓMEZ, J., VIDAL, M. and NEIRA, J.L. (2007). Biochemistry the isolated C-terminal domain of Ring1B is a dimer made of stable, well-structured monomers. Biochemistry. 46: 12764-12776.

DE NAPOLES, M., MERMOUD, J.E., WAKAO, R., TANG, Y.A., ENDOH, M., APPANAH, R., NESTEROVA, T.B., SILVA, J., OTTE, A.P., VIDAL, M., ET AL. (2004). Polycomb group proteins Ring1A/B link ubiquitylation of histone $\mathrm{H} 2 \mathrm{~A}$ to heritable gene silencing and $X$ inactivation. Dev. Cell 7: 663-676.

DE SANTA, F., TOTARO, M.G., PROSPERINI, E., NOTARBARTOLO, S., TESTA, G. and NATOLI, G. (2007) The histone H3 lysine-27 demethylase Jmjd3 links inflammation to inhibition of Polycomb-mediated gene silencing. Cell 130: 10831094.

DEl mar loRente, M., MARCos-gutiérRez, C., PÉREz, C. SCHOORLEMMER, J., RAMÍREZ, A., MAGIN, T. and VIDAL, M. (2000). Lossand gain-of-function mutations show a polycomb group function for Ring1 $\mathrm{A}$ in mice. Development 127: 5093-5100.

DELLINO, G.I., SCHWARTZ, Y.B., FARKAS, G., MCCABE, D., ELGIN, S.C. and PIRROTTA, V. (2004). Polycomb silencing blocks transcription initiation. Mol. Cell 13: 887-893.

DIETRICH, N., BRACKEN, A.P., TRINH, E., SCHJERLING, C.K., KOSEKI, H., RAPPSILBER, J., HELIN, K. and HANSEN, K.H. (2007). Bypass of senescence by the polycomb group protein $\mathrm{CBX} 8$ through direct binding to the INK4A-ARF locus. EMBO. J. 26: 1637-1648.

DOU, Y., MILNE, T.A., TACKETT, A.J., SMITH, E.R., FUKUDA, A., WYSOCKA, J., ALLIS, C.D., CHAIT, B.T., HESS, J.L. and ROEDER, R.G. (2005). Physical association and coordinate function of the $\mathrm{H} 3 \mathrm{~K} 4$ methyltransferase MLL1 and the $\mathrm{H} 4 \mathrm{~K} 16$ acetyltransferase MOF. Cell 121: 873-885.

DUKERS, D.F., VAN GALEN, J.C., GIROTH, C., JANSEN, P., SEWALT, R.G., OTTE, A.P., KLUIN-NELEMANS, H.C., MEIJER, C.J. and RAAPHORST, F.M. (2004). Unique polycomb gene expression pattern in Hodgkin's lymphoma and Hodgkin's lymphoma-derived cell lines. Am. J. Pathol. 164: 873-881.

ELDERKIN, S., MAERTENS, G.N., ENDOH, M., MALLERY, D.L., MORRICE, N., KOSEKI, H., PETERS, G., BROCKDORFF, N. and HIOM, K. (2007). A phosphorylated form of Mel-18 targets the Ring1B histone H2A ubiquitin ligase to chromatin. Mol. Cell 28: 107-120.

ENDOH, M., ENDO, T.A., ENDOH, T., FUJIMURA, Y., OHARA, O., TOYODA, T., OTTE, A.P., OKANO, M., BROCKDORFF, N., VIDAL, M., etal. (2008). Polycomb group proteins Ring1A/B arefunctionally linked to the core transcriptional regulatory circuitry to maintain ES cell identity. Development 135: 1513-1524.

FANG, J., CHEN, T., CHADWICK, B., LI, E. and ZHANG, Y. (2004). Ring1bmediated $\mathrm{H} 2 \mathrm{~A}$ ubiquitination associates with inactive $X$ chromosomes and is involved in Initiation of X-inactivation. J. Biol. Chem. 279: 52812-52815.

FARRIS, S.D., RUBIO, E.D., MOON, J.J., GOMBERT, W.M., NELSON, B.H. and KRUMM, A. (2005) Transcription-induced chromatin remodeling at the c-myc gene involves the local exchange of histone H2A.Z. J. Biol. Chem. 280: 2529825303.

FISCHLE, W., WANG, Y., JACOBS, S.A., KIM, Y., ALLIS, C.D. and KHORASANIZADEH, S. (2003). Molecular basis for the discrimination of repressive methyl-lysine marks in histone $\mathrm{H} 3$ by Polycomb and HP1 chromodomains. Genes Dev. 17: 1870-1881.

FRANCIS, N.J. and KINGSTON, R.E. (2001a). Mechanisms of transcriptional memory. Nat. Rev. Mol. Cell. Biol. 2: 409-421.

FRANCIS, N.J., SAURIN, A.J., SHAO, Z. and KINGSTON, R.E. (2001b). Reconstitution of a functional core polycomb repressive complex. Mol. Cell 8: 545-556.

FRANCIS, N.J., KINGSTON, R.E. and WOODCOCK, C.L. (2004). Chromatin compaction by a polycomb group protein complex. Science. 306: 1574-1577.

FRITSCH, C., BEUCHLE, D. and MÜLLER, J. (2003). Molecular and genetic analysis of the Polycomb group gene Sex combs extra/Ring in Drosophila. Mech. Dev. 120: 949-954.

GARCÍA, E., MARCOS-GUTIÉRREZ, C., DEL MAR LORENTE, M., MORENO, J.C. and VIDAL, M. (1999). RYBP, a new repressor protein that interacts with components of the mammalian Polycomb complex, and with the transcription factor YY1. EMBO. J. 18: 3404-3418.

GEARHART,M.D., CORCORAN, C.M., WAMSTAD, J.A. and BARDWELL, V.J. (2006). Polycomb Group and SCF Ubiquitin Ligases Are Found in a Novel BCOR Complex That Is Recruited to BCL6 Targets. Mol. Cell. Biol. 26: 68806889.

GÉVRY, N., CHAN, H.M., LAFLAMME, L., LIVINGSTON, D.M. and GAUDREAU, L. (2007). p21 transcription is regulated by differential localization of histone H2A.Z. Genes Dev. 21: 1869-1881.

GIL, J. and PETERS, G. (2006). Regulation of the INK4b-ARF-INK4a tumour suppressor locus: all for one or one for all. Nat. Rev. Mol. Cell. Biol. 7: 667-677.

GLINSKY, G.V., BEREZOVSKA, O. and GLINSKII, A.B. (2005). Microarray analysis identifies a death-from-cancer signature predicting therapy failure in patients with multiple types of cancer. J. Clin. Invest. 115: 1503-1521.

GOLDKNOPF, I.L., SUDHAKAR, S., ROSENBAUM, F. and BUSCH, H. (1980) Biochemical and biophysical research communications timing of ubiquitin synthesis and conjugation into protein A24 during the HeLa cell cycle. Biochem. Biophys. Res. Commun. 95: 1253-1260.

GORFINKIEL, N., FANTI, L., MELGAR, T., GARCÍA, E., PIMPINELLI, S., GUERRERO, I. and VIDAL, M. (2004). The Drosophila Polycomb group gene Sex combs extra encodes the ortholog of mammalian Ring1 proteins. Mech. Dev. 121: 449-462.

GRIMAUD, C., NÈGRE, N. and CAVALLI, G. (2006). From genetics to epigenetics: the tale of Polycomb group and trithorax group genes. Chromosome Res. 14: 363-375.

GUENTHER, M.G., LEVINE, S.S., BOYER, L.A., JAENISCH, R. and YOUNG, R.A. (2007). A chromatin landmark and transcription initiation at most promoters in human cells. Cell 130: 77-88.

HANSON, I.M., POUSTKA, A. and TROWSDALE, J. (1991). Genomics New genes in the class II region of the human major histocompatibility complex. Genomics 10: 417-424.

HEARD, E. and DISTECHE, C.M. (2006). Dosage compensation in mammals: finetuning the expression of the X chromosome. Genes Dev. 20: 1848-1867.

HEMENWAY, C.S., HALLIGAN, B.W. and LEVY, L.S. (1998). The Bmi-1 oncoprotein interacts with dinG and MPh2: the role of RING finger domains. Oncogene 16: 2541-2547.

HEMENWAY, C.S., HALLIGAN, B.W., GOULD, G.C. and LEVY, L.S. (2000). Identification and analysis of a third mouse Polycomb gene, MPc3. Gene. 242: 31-40.

ISHIKAWA, F.F., YOSHIDA, S., SAITO, Y., HIJIKATA, A., KITAMURA, H., TANAKA, S., NAKAMURA, R., TANAKA, T., TOMIYAMA, H., SAITO, N., ET AL. (2007). Chemotherapy-resistant human AML stem cells home to and engraft within the 
bone-marrow endosteal region. Nat. Biotechnol. 25: 1315-1321.

IWAMA, A., OGURO, H., NEGISHI, M., KATO, Y., MORITA, Y., TSUKUI H., EMA, H., KAMIJO, T., KATOH-FUKUI, Y., KOSEKI, H., et al. (2004). Enhanced selfrenewal of hematopoietic stem cells mediated by the polycomb gene product bmi-1. Immunity 21: 843-851.

JASON, L.J., FINN, R.M., LINDSEY, G. and AUSIÓ, J. (2005). Histone H2A ubiquitination does not preclude histone $\mathrm{H} 1$ binding, but it facilitates its association with the nucleosome. J. Biol. Chem. 280: 4975-4982.

JOO, H.Y., ZHAI, L., YANG, C., NIE, S., ERDJUMENT-BROMAGE, H., TEMPST, P., CHANG, C. and WANG, H. (2007). Regulation of cell cycle progression and gene expression by H2A deubiquitination. Nature 449: 1068-1072.

KARAKUZU, O., WANG, D.P. and CAMERON, S. (2009) MIG-32 and SPAT-3A are PRC1 homologs that control neuronal migration in Caenorhabditis elegans. Development 136: 943-953.

KERSCHER, O., FELBERBAUM, R. and HOCHSTRASSER, M. (2006). Modification of proteins by ubiquitin and ubiquitin-like proteins. Annu. Rev. Cell. Dev. Biol. 22: 159-180.

KIA, S.K., GORSKI, M.M., GIANNAKOPOULOS, S. and VERRIJZER CP. (2008) SWI/SNF mediates polycomb eviction and epigenetic reprogramming of the INK4b-ARF-INK4a locus. Mol. Cell. Biol. 28:3457-3464.

KRIVTSOV, A.V. and ARMSTRONG, S.A. (2007). MLL translocations, histone modifications and leukaemia stem-cell development. Nat. Rev. Cancer 7: 823833.

KU, M., KOCHE, R., RHEINBAY, E., MENDENHALL, E.M., ENDOH, M., MIKKELSEN, T.S., PRESSER, A., NUSBAUM, C., XIE, X., CHI, A., ADLI, M., KASIF, S., PTASZEK, L., COWAN, C., LANDER, E.S., KOSEKI, H."and BERNSTEIN, B.E. (2008). Genomewide analysis of PRC1 and PRC2 occupancy identifies two classes of bivalent domains. PLoS Genetics 4: e1000242

LANZUOLO, C., ROURE, V., DEKKER, J., BANTIGNIES, F. and ORLANDO, V. (2007). Polycomb response elements mediate the formation of chromosome higher-order structures in the bithorax complex. Nat. Cell Biol. 9: 1167-1174.

LEE, S.J., CHOI, J.Y., SUNG, Y.M., PARK, H., RHIM, H. and Kang, S. (2001). E3 ligase activity of RING finger proteins that interact with $\mathrm{Hip}-2$, a human ubiquitinconjugating enzyme. FEBS Lett. 503: 61-64.

LEE, S.J., CHOI, D., RHIM, H. and KANG, S. (2005). E3 ubiquitin ligase RNF2 interacts with the S6' proteasomal ATPase subunit and increases the ATP hydrolysis activity of S6'. Biochem. J. 389: 457-463.

LEE, T.I., JENNER, R.G., BOYER, L.A., GUENTHER, M.G., LEVINE, S.S., KUMAR, R.M., CHEVALIER, B., JOHNSTONE, S.E., COLE, M.F., ISONO, K., ET AL. (2006). Control of developmental regulators by polycomb in human embryonic stem cells. Cell 125: 301-313.

LEE, M.G., VILLA, R., TROJER, P., NORMAN, J., YAN, K.P., REINBERG, D., DI CROCE, L. and SHIEKHATTAR, R. (2007). Demethylation of H3K27 regulates polycomb recruitment and H2A ubiquitination. Science 318: 447-450.

LEE, J., SON, M.J., WOOLARD, K., DONIN, N.M., LI, A., CHENG, C.H., KOTLIAROVA, S., KOTLIAROV, Y., WALLING, J., AHN, S., ET AL. (2008). Epigenetic-mediated dysfunction of the bone morphogenetic protein pathway inhibits differentiation of glioblastoma-initiating cells. Cancer Cell 13: 69-80.

LEEB, M. and WUTZ, A. (2007). Ring1B is crucial for the regulation of developmental control genes and PRC1 proteins but not $\mathrm{X}$ inactivation in embryonic cells. J. Cell Biol. 178: 219-229.

LESSARD, J. and SAUVAGEAU, G. (2003). Bmi-1 determines the proliferative capacity of normal and leukaemic stem cells. Nature 423: 255-260.

LEVINE,S.S., WEISS, A., ERDJUMENT-BROMAGE, H., SHAO, Z., TEMPST, P. and KINGSTON, R.E. (2002). The core of the polycomb repressive complex is compositionally and functionally conserved in flies and humans. Mol. Cell. Biol. 22: $6070-6078$

LI, Z., CAO, R., WANG, M., MYERS, M.P., ZHANG, Y. and XU, R.M. (2006). Structure of a BMI-1-ring1B polycomb group ubiquitin ligase complex. J. Biol. Chem. 281: 20643-20649.

LIU, S., DONTU, G., MANTLE, I.D., PATEL, S., AHN, N.S., JACKSON, K.W., SURI, P. and WICHA, M.S. (2006). Hedgehog signaling and Bmi-1 regulate selfrenewal of normal and malignant human mammary stem cells. Cancer Res. 66: 6063-6071.

LORENTE, M., PÉREZ, C., SÁNCHEZ, C., DONOHOE, M., SHI, Y. and VIDAL, M. (2006). Homeotic transformations of the axial skeleton of YY1 mutant mice and genetic interaction with the Polycomb group gene Ring1/Ring1A. Mech. Dev. 123: 312-320.

LOVERING, R., HANSON, I.M., BORDEN, K.L., MARTIN, S., O'REILLY, N.J., EVAN, G.I., RAHMAN, D., PAPPIN, D.J., TROWSDALE, J. and FREEMONT, P.S. (1993). Identification and preliminary characterization of a protein motif related to the zinc finger. Proc. Natl. Acad. Sci. USA 90: 2112-2116.

MAGER, J., MONTGOMERY, N.D., DE VILLENA, F.P. and MAGNUSON, T. (2003). Genome imprinting regulated by the mouse Polycomb group protein Eed. Nat. Genet. 33: 502-507.

MAILAND, N., BEKKER-JENSEN, S., FAUSTRUP, H., MELANDER, F., BARTEK, J., LUKAS, C. and LUKAS J. (2007). RNF8 ubiquitylates histones at DNA double-strand breaks and promotes assembly of repair proteins. Cell 131: 887900.

MARGUERON, R., LI, G., SARMA, K., BLAIS, A., ZAVADIL, J., WOODCOCK, C.L., DYNLACHT, B.D. and REINBERG, D. (2008) Ezh1 and Ezh2 maintain repressive chromatin through different mechanisms. Mol. Cell 32: 503-518.

MATSUI, S.I., SEON, B.K. and SANDBERG, A.A. (1979). Disappearance of a structural chromatin protein A24 in mitosis: implications for molecular basis of chromatin condensation. Proc. Natl. Acad. Sci. USA 76: 6386-6390.

MIKKELSEN, T.S., KU, M., JAFFE, D.B., ISSAC, B., LIEBERMAN, E., GIANNOUKOS, G., ALVAREZ, P., BROCKMAN, W., KIM, T.K., KOCHE, R.P., et al.n (2007). Genome-wide maps of chromatin state in pluripotent and lineagecommitted cells. Nature 448: 553-560.

MIN, J., ZHANG, Y. and XU, R.M. (2003). Structural basis for specific binding of Polycomb chromodomain to histone H3 methylated at Lys 27 . Genes Dev. 17: 1823-1828.

MOHN F, WEBER M, REBHAN M, ROLOFF TC, RICHTER J, STADLER MB, BIBEL M. and SCHÜBELER, D. (2008). Lineage-Specific Polycomb Targets and De Novo DNA Methylation Define Restriction and Potential of Neuronal Progenitors. Mol. Cell 30: 755-766.

MUELLER, D., BACH, C., ZEISIG, D., GARCIA-CUELLAR, M.P., MONROE, S., SREEKUMAR, A., ZHOU, R., NESVIZHSKII, A., CHINNAIYAN, A., HESS, J.L., et al. (2007) A role for the MLL fusion partner ENL in transcriptional elongation and chromatin modification. Blood 110: 4445-4454.

MURRELL, A., HEESON, S. and REIK, W. (2004). Interaction between differentially methylated regions partitions the imprinted genes Igf2 and $\mathrm{H} 19$ into parentspecific chromatin loops. Nat. Genet. 36: 889-893.

MUSE, G.W., GILCHRIST, D.A., NECHAEV, S., SHAH, R., PARKER, J.S., GRISSON, S.F., ZEITLINGER, J. and ADELMAN,K. (2007). RNA polymerase is poised for activation across the genome. Nat. Genet. 39: 1507-1511.

MÜLLER, J. and KASSIS, J.A. (2006). Polycomb response elements and targeting of Polycomb group proteins in Drosophila. Curr. Opin. Genet. Dev. 16: 476-484.

NAKAGAWA, T., KAJITANI, T., TOGO, S., MASUKO, N., OHDAN, H., HISHIKAWA Y., KOJI, T., MATSUYAMA, T., IKURA, T., MURAMATSU, M., et al. (2008). Deubiquitylation of histone $\mathrm{H} 2 \mathrm{~A}$ activates transcriptional initiation via transhistone cross-talk with H3K4 di- and trimethylation. Genes Dev. 22: 37-49.

NĖGRE, N., HENNETIN, J., SUN, L.V., LAVROV, S., BELLIS, M., WHITE, K.P. and CAVALLI, G. (2006). Chromosomal distribution of PcG proteins during Drosophila development. PLOS. Biol. 4: e170.

NEIRA, J.L., ROMAN-TRUFERO, M., CONTRERAS, L.M., PRIETO, J., SINGH, G. BARRERA, F.N., RENART, M.L. and VIDAL, M. (2009) The transcriptional repressor RYBP is natively unfolded protein which folds upon binding to DNA. Biochemistry, 48:1348-1360.

NICASSIO, F., CORRADO, N., VISSERS, J.H., ARECES, L.B., BERGINK, S. MARTEIJN, J.A., GEVERTS, B., HOUTSMULLER, A.B., VERMEULEN,W., DI FIORE, P.P., et al. (2007). Human USP3 is a chromatin modifier required for $S$ phase progression and genome stability. Curr. Biol. 17: 1972-1977.

NICKEL, B.E. and DAVIE, J.R. (1989). Structure of polyubiquitinated histone H2A. Biochemistry 28: 964-968.

NIJMAN, S.M.B., LUNA-VARGAS, M.P.A., VELDS, A., BRUMMELKAMP, T.R., DIRAC, A.M.G., SIXMA, T.K. and BERNARDS, R. (2005). A genomic and functional inventory of deubiquitinating enzymes. Cell 123: 773-786.

NIWA, H. (2007). Open conformation chromatin and pluripotency. Genes Dev. 21: 2671-2676.

OGAWA, H., ISHIGURO, K., GAUBATZ, S., LIVINGSTON, D.M. and NAKATANI, Y. (2002). A complex with chromatin modifiers that occupies E2F- and Myc- 
responsive genes in G0 cells. Science 296: 1132-1136.

OHM, J., MCGARVEY, K., YU, X., CHENG, L., SCHUEBEL, K., COPE, L., MOHAMMAD, H., CHEN, W., DANIEL V., YU W., et al. (2007). A stem cell -like chromatin pattern may predispose tumor suppressor genes to DNA hypermethylation and heritable silencing. Nat. Genet. 39: 237-242.

PAN, G., TIAN, S., NIE, J., YANG, C., RUOTTI, V., WEI, H., JONSDOTTIR, G.A., STEWART, R. and THOMSON, J.A. (2007). Whole-genome analysis of histone $\mathrm{H} 3$ lysine 4 and lysine 27 methylation in human embryonic stem cells. Cell Stem Cell 1: 458-469.

PARK, I.K., QIAN, D., KIEL, M., BECKER, M.W., PIHALJA, M., WEISSMAN, I.L., MORRISON, S.J. and CLARKE, M.F. (2003). Bmi-1 is required for maintenance of adult self-renewing haematopoietic stem cells. Nature 423: 302-305.

PASINI, D., BRACKEN, A.P., HANSEN, J.B., CAPILLO, M. and HELIN, K. (2007). The Polycomb group protein Suz12 is required for embryonic stem cell differentiation. Mol. Cell. Biol. 27: 3769-3779

PETREY, D., XIANG, Z., TANG, C.L., XIE L., GIMPELEV, M., MITROS, T., SOTO, C.S., GOLDSMITH-FISCHMAN, S., KERNYTSKY, A., SCHLESSINGER, A., et al. (2003). Using multiple structure alignments, fast model building, and energetic analysis in fold recognition and homology modeling. Proteins. 53 Suppl 6: 430-435.

PLATH, K., FANG, J., MLYNARCZYK-EVANS, S.K., CAO, R., WORRINGER, K.A., WANG, H., DE LA CRUZ, C.C., OTTE, A.P., PANNING, B. and ZHANG, Y. (2003). Role of histone $\mathrm{H} 3$ lysine 27 methylation in $X$ inactivation. Science 300 : 131-135.

PLATH, K., TALBOT, D., HAMER, K.M., OTTE, A.P., YANG, T.P., JAENISCH, R. and PANNING, B. (2004). Developmentally regulated alterations in Polycomb repressive complex 1 proteins on the inactive X chromosome. J. Cell Biol. 167: 1025-1035.

PUSCHENDORF, M., TERRANOVA, R., BOUTSMA, E., MAO, X., ISONO, K., BRYKCZYNSKA, U., KOLB, C., OTTE, A., KOSEKI, H., ORKIN S., et al. (2008). PRC1 and Suv39h specify parental asymmetry at constitutive heterochromatin in early mouse embryos. Nat.Genet. 40: 411-420.

QIN, H., WANG, J., LIANG, Y., TANIGUCHI, Y., TANIGAKI, K. and HAN, H. (2004). RING1 inhibits transactivation of RBP-J by Notch through interaction with LIM protein KyoT2. Nucleic Acids Res. 32: 1492-1501.

RAAPHORST, F.M., VERMEER, M., FIERET, E., BLOKZIJL, T., DUKERS, D., SEWALT, R.G., OTTE, A.P., WILLEMZE, R. and MEIJER, C.J. (2004). Sitespecific expression of polycomb-group genes encoding the HPC-HPH/PRC1 complex in clinically defined primary nodal and cutaneous large B-cell lymphomas. Am. J. Pathol. 164: 533-542.

RAJASEKHAR, V.K. and BEGEMANN, M. (2007). Roles of polycomb group proteins in development and disease: a stem cell perspective. Stem Cells 25: 2498-2510.

RINGROSE, L. and PARO, R. (2004). Epigenetic regulation of cellular memory by the polycomb and trithorax group proteins. Annu. Rev. Genet. 38: 413-443.

RINGROSE, L. and PARO, R. (2007). Polycomb/Trithorax response elements and epigenetic memory of cell identity. Development 134: 223-232.

ROH, T.Y., CUDDAPAH, S., CUI, K. and ZHAO, K. (2006) The genomic landscape of histone modifications in human T cells. Proc. Natl. Acad. Sci. USA 103: 15782-15787.

ROMÁN-TRUFERO, M., MÉNDEZ-GÓMEZ, H., PÉREZ C., HIJIKATA, A., FUJIMURA, Y., ENDO, T., KOSEKI, H., VICARIO-ABEJÓN, C. and VIDAL, M. (2009). Maintenance of undifferentiated state and self-renewal of embryonic neural stem cells by Polycomb protein Ring1B. Stem Cells [DOI: 10.1002/ stem.82]

SARCINELLA, E., ZUZARTE, P.C., LAU, P.N., DRAKER, R. and CHEUNG, P. (2007). Monoubiquitylation of H2A.Z distinguishes its association with euchromatin or facultative heterochromatin. Mol. Cell. Biol. 27: 6457-6468.

SATIJN, D.P., GUNSTER, M.J., VAN DER VLAG, J., HAMER, K.M., SCHUL, W., ALKEMA, M.J., SAURIN, A.J., FREEMONT, P.S., VAN DRIEL, R. and OTTE, A.P. (1997). RING1 is associated with the polycomb group protein complex and acts as a transcriptional repressor. Mol. Cell. Biol. 17: 4105-4113.

SATIJN, D.P. and OTTE, A.P. (1999). RING1 interacts with multiple Polycombgroup proteins and displays tumorigenic activity. Mol. Cell. Biol. 19: 57-68.

SAURIN, A.J., BORDEN, K.L., BODDY, M.N. and FREEMONT, P.S. (1996). Does this have a familiar RING? Trends Biochem. Sci. 21: 208-214.
SAURIN, A.J., SHAO, Z., ERDJUMENT-BROMAGE, H., TEMPST, P. and KINGSTON, R.E. (2001). A Drosophila Polycomb group complex includes Zeste and dTAFII proteins. Nature 412: 655-660.

SÁNCHEZ, C., SÁNCHEZ, I., DEMMERS, J.A., RODRIGUEZ, P., STROUBOULIS, J. and VIDAL, M. (2007). Proteomic analysis of Ring1B/Rnf2 interactors identifies a novel complex with the Fbxl10/ Jmjd1B histone demethylase and the BcoR corepressor. Mol. Cell. Proteomics 6: 820-834.

SÁNCHEZ-BEATO, M., SÁNCHEZ, E., GARCÍA, J.F., PÉREZ-ROSADO, A., MONTOYA, M.C., FRAGA, M., ARTIGA, M.J., NAVARRETE, M., ABRAIRA, V., MORENTE, M., ET AL. (2004). Abnormal PcG protein expression in Hodgkin's lymphoma. Relation with E2F6 and NFkappaB transcription factors. J. Pathol. 204: 528-537.

SÁNCHEZ-BEATO, M., SÁNCHEZ, E., GONZÁLEZ-CARRERA, J., MORENTE, M., DÍEZ, A., SÁNCHEZ-VERDE, L., MARTÍN, M.C., CIGUDOSA, J.C., VIDAL, M. and PIRIS, M.A. (2006). Variability in the expression of polycomb proteins in different normal and tumoral tissues. A pilot study using tissue microarrays. Mod. Pathol. 19: 684-694.

SCHLESINGER, Y., STRAUSSMAN, R., KESHET, I., FARKASH, S., HECHT, M., ZIMMERMAN, J., EDEN, E., YAKHINI, Z., BEN-SHUSHAN, E., REUBINOFF, B.E., et al. (2006). Polycomb-mediated methylation on Lys27 of histone H3 premarks genes for de novo methylation in cancer. Nat. Genet. 32: 232-236.

SCHOEFTNER, S., SENGUPTA, A.K., KUBICEK, S., MECHTLER, K., SPAHN, L., KOSEKI, H., JENUWEIN, T. and WUTZ A. (2006). Recruitment of PRC1 function at the initiation of $X$ inactivation independent of PRC2 and silencing. EMBO J. 25: 3110-3122.

SCHOORLEMMER, J., MARCOS-GUTIÉRREZ, C., WERE, F., MARTÍNEZ, R., GARCÍA, E., SATIJN, D.P., OTTE, A.P. and"VIDAL, M. (1997). Ring1A is a transcriptional repressor that interacts with the Polycomb-M33 protein and is expressed at rhombomere boundaries in the mouse hindbrain. EMBO J. 16: 5930-5942.

SCHUETTENGRUBER, B., CHOURROUT, D., VERVOORT, M., LEBLANC, B. and CAVALLI, G. (2007). Genome regulation by polycomb and trithorax proteins. Cell 128: 735-745.

SCHWARTZ, Y.B., KAHN, T.G., NIX, D.A., LI, X.Y., BOURGON, R., BIGGIN, M. and PIRROTTA, V. (2006) Genome-wide analysis of Polycomb targets in Drosophila melanogaster. Nat. Genet. 38: 700-705.

SCHWARTZ, Y.B. and PIRROTTA, V. (2007). Polycomb silencing mechanisms and the management of genomic programmes. Nat. Rev. Genet. 8: 9-22.

SHAO, Z., RAIBLE, F., MOLLAAGHABABA, R., GUYON, J.R., WU, C.T., BENDER, W. and KINGSTON, R.E. (1999). Stabilization of chromatin structure by PRC1, a Polycomb complex. Cell 98: 37-46.

SHILATIFARD, A. (2006). Chromatin modifications by methylation and ubiquitination: implications in the regulation of gene expression. Annu. Rev. Biochem. 75: 243269.

SILVA, J., MAK, W., ZVETKOVA, I., APPANAH, R., NESTEROVA, T.B., WEBSTER, Z., PETERS, A.H., JENUWEIN, T., OTTE, A.P. and BROCKDORFF, N. (2003). Establishment of histone $\mathrm{H} 3$ methylation on the inactive $X$ chromosome requires transient recruitment of Eed-Enx1 polycomb group complexes. Dev. Cell 4: 481-495.

SPARMANN, A. and VAN LOHUIZEN, M. (2006). Polycomb silencers control cell fate, development and cancer. Nat. Rev. Cancer 6: 846-856.

STOCK, J., GIADROSSI, S., CASANOVA, M., BROOKES, E., VIDAL, M., KOSEKI, H., BROCKDORFF, N., FISHER A. and POMBO, A. (2007). Ring1-mediated ubiquitination of $\mathrm{H} 2 \mathrm{~A}$ restrains poised RNA polymerase II at bivalent genes in mouse ES cells. Nat. Cell Biol. 9: 1428-1435.

SUZUKI, M., MIZUTANI-KOSEKI, Y., FUJIMURA, Y., MIYAGISHIMA, H., KANEKO, T., TAKADA, Y., AKASAKA, T., TANZAWA, H., TAKIHARA, Y., NAKANO, M., et al. (2002). Involvement of the Polycomb-group gene Ring1B in the specification of the anterior-posterior axis in mice. Development 129: 4171-4183.

TAHILIANI, M., MEI, P., FANG, R., LEONOR, T., RUTENBERG, M., SHIMIZU, F., LI J., RAO, A. and SHI, Y. (2007). The histone H3K4 demethylase SMCX links REST target genes to X-linked mental retardation. Nature. 447: 601-605.

TAVERNA, S.D., LI, H., RUTHENBURG, A.J., ALLIS, C.D. and PATEL, D.J. (2007). How chromatin-binding modules interpret histone modifications: lessons from professional pocket pickers. Nat. Struct. Mol. Biol. 14: 1025-1040.

TIWARI, V.K., MCGARVEY, K.M., LICCHESI, J.D., OHM, J.E., HERMAN, J.G., 
SCHÜBELER, D. and BAYLIN, S.B. (2008). PcG Proteins, DNA Methylation, and Gene Repression by Chromatin Looping. PLoS Biol. 6:e306.

TOLHUIS, B., MUIJRERS, I., DE WIT, E., TEUNISSEN, H., TALHOUT, W., VAN STEENSEL, B. and VAN LOHUIZEN, M. (2006). Genome-wide profiling of PRC1 and PRC2 Polycomb chromatin binding in Drosophila melanogaster. Nat. Genet. 38: 694-699.

TRIMARCHI, J.M. and LEES, J.A. (2002). Sibling rivalry in the E2F family Nat. Rev. Mol. Cell. Biol. 3: 11-20.

TUCKFIELD, A., CLOUSTON, D.R., WILANOWSKI, T.M., ZHAO, L.L., CUNNINGHAM, J.M. and JANE, S.M. (2002). Binding of the RING polycomb proteins to specific target genes in complex with the grainyhead-like family of developmental transcription factors. Mol. Cell. Biol. 22: 1936-1946.

VALK-LINGBEEK, M.E., BRUGGEMAN, S.W. and VAN LOHUIZEN, M. (2004). Stem cells and cancer; the polycomb connection. Cell 118: 409-418.

VAN DER VLAG, J. and OTTE, A.P. (1999). Transcriptional repression mediated by the human polycomb-group protein EED involves histone deacetylation. Nat. Genet. 23: 474-478.

VAN LEENDERS, G.J., DUKERS, D., HESSELS, D., VAN DEN KIEBOOM, S.W., HULSBERGEN, C.A., WITJES, J.A., OTTE, A.P., MEIJER, C.J. and RAAPHORST, F.M. (2006). Polycomb-Group Oncogenes EZH2, BMI1, and RING1 Are Overexpressed in Prostate Cancer With Adverse Pathologic and Clinical Features. Eur. Urol. 52: 455-463.

VERMEULEN, M., MULDER, K.W., DENISSOV, S., PIJNAPPEL, W.W., VAN SCHAIK, F.M., VARIER, R.A., BALTISSEN, M.P., STUNNENBERG, H.G., MANN, M. and TIMMERS, H.T. (2007). Anchoring of TFIID to nucleosomes by trimethylation of histone $\mathrm{H} 3$ lysine 4. Cell 131: 58-69.

VONCKEN, J.W., ROELEN, B.A., ROEFS, M., DE VRIES, S., VERHOEVEN, E., MARINO, S., DESCHAMPS, J. and VAN LOHUIZEN, M. (2003). Rnf2 (Ring1b) deficiency causes gastrulation arrest and cell cycle inhibition. Proc. Natl. Acad. Sci. USA 100: 2468-2473.

WANG, H., WANG, L., ERDJUMENT-BROMAGE, H., VIDAL, M., TEMPST, P., JONES, R.S. and ZHANG Y. (2004). Role of histone H2A ubiquitination in Polycomb silencing. Nature 431: 873-878.

WEI, J., ZHAI, L., XU, J. and WANG, H. (2006). Role of Bmi1 in H2A ubiquitylation and hox gene silencing. J. Biol. Chem. 281: 22537-22544.

WHITCOMB, S.J., BASU, A., ALLIS, C.D. and BERNSTEIN, E. (2007). Polycomb group proteins: an evolutionary perspective. Trends Genet. 23: 494-502.

WIDSCHWENDTER, M., FIEGL, H., EGLE, D., MUELLER-HOLZNER, E., SPIZZO, G., MARTH, C., WEISENBERGER, D.J., CAMPAN, M., YOUNG, J., JACOBS, I., et al. (2006). Epigenetic stem cell signature in cancer. Nat. Genet. 39: 157-158.
WIEDERSCHAIN, D., CHEN, L., JOHNSON, B., BETTANO, K., JACKSON, D., TARASZKA, J., WANG, Y.K., JONES, M.D., MORRISSEY, M., DEEDS, J., et al. (2007). Contribution of polycomb homologues Bmi-1 and Mel-18 to medulloblastoma pathogenesis. Mol. Cell. Biol. 27: 4968-4979.

WONG, C.K., CHEN, Z., SO, K.L., LI, D. and LI, P. (2007). Polycomb group protein RING1B is a direct substrate of caspases-3 and -9. Biochim. Biophys. Acta 1773: 844-852.

ZEITLINGER, J., STARK, A., KELLIS, M., HONG, J., NECHAEV, S.W., ADELMAN, K., LEVINE, M. and YOUNG, R.A. (2007). RNA polymerase stalling at developmental control genes in the Drosophila melanogaster embryo. Nat. Genet. 39: 1512-1516.

ZHANG, H., CHRISTOFOROU, A., ARAVIND, L., EMMONS, S.W., VAN DEN HEUVEL, S. and HABER, D.A. (2004). The C. elegans Polycomb gene sop-2 encodes an RNA binding protein. Mol. Cell 14: 841-847.

ZHANG, X.Y., VARTHI, M., SYKES, S.M., PHILLIPS, C., WARZECHA, C., ZHU, W., WYCE, A., THORNE, A.W., BERGER, S.L. and MCMAHON, S.B. (2008). The putative cancer stem cell marker USP22 is a subunit of the human SAGA complex required for activated transcription and cell-cycle progression. Mol. Cell 29: 102-111.

ZHAO, X.D., HAN, X., CHEW, J.L., LIU, J., CHIU, K.P., CHOO, A., ORLOW, Y.L., SUNG, W.-.K., SHAHAB, A., KUZNETSOV, V., et al. (2007). Whole-genome mapping of histone $\mathrm{H} 3$ lys 4 and 27 trimethylations reveals distinct genomic compartments in human embryonic stem cells. Cell Stem Cell 1: 286-298.

ZHAO, Y., LANG, G., ITO, S., BONNET, J., METZGER, E., SAWATSUBASHI, S., SUZUKI, E., LE GUEZENNEC, X., STUNNENBERG, H.G., KRASNOV, A., et al.(2008) A TFTC/STAGA module mediates histone H2A and H2B deubiquitination, coactivates nuclear receptors, and counteracts heterochromatin silencing. Mol. Cell 29: 92-101.

ZHOU, W., ZHU, P., WANG, J., PASCUAL, G., OHGI, K.A., LOZACH, J., GLASS, C.K. and ROSENFELD, M.G. (2008). Histone H2A monoubiquitination represses transcription by inhibiting RNA polymerase II transcriptional elongation. Mol. Cell 29: 69-80.

ZHU, P., ZHOU, W., WANG, J., PUC, J., OHGI, K.A., ERDJUMENT-BROMAGE, H., TEMPST, P., GLASS, C.K. and ROSENFELD, M.G. (2007). A histone H2A deubiquitinase complex coordinating histone acetylation and $\mathrm{H} 1$ dissociation in transcriptional regulation. Mol. Cell 27: 609-621.

ZINK, B. and PARO, R. (1989). In vivo binding pattern of a trans-regulator of homoeotic genes in Drosophila melanogaster. Nature 337: 468-471. 


\section{Further Related Reading, published previously in the Int. J. Dev. Biol.}

See our Special Issue Fertilization edited by Paul M. Wassarman and Victor D. Vacquier at: http://www.ijdb.ehu.es/web/contents.php?vol=52\&issue=5-6

Drosophila retinal pigment cell death is regulated in a position-dependent manner by a cell memory gene Nicolas Dos-Santos, Thomas Rubin, Fabienne Chalvet, Pierre Gandille, Frederic Cremazy, Jacqueline Leroy, E. Boissonneau and Laurent Théodore

Int. J. Dev. Biol. (2008) 52: 21-31

Control of reproduction by Polycomb Group complexes in animals and plants Anne-Elisabeth Guitton and Frederic Berger Int. J. Dev. Biol. (2005) 49: 707-716

The Drosophila pleiohomeotic mutation enhances the Polycomblike and Polycomb mutant phenotypes during embryogenesis and in the adult.

Seung-Hae Kwon, Sang Hee Kim, Hae-Moon Chung, Jack R Girton and Sang-Hak Jeon Int. J. Dev. Biol. (2003) 47: 389-395

Extensive conservation of sequences and chromatin structures in the bxd polycomb response element among Drosophilid species.

Gaetano I Dellino, Christophe Tatout and Vincenzo Pirrotta

Int. J. Dev. Biol. (2002) 46: 133-141

Initiation, establishment and maintenance of Hox gene expression patterns in the mouse.

J Deschamps, E van den Akker, S Forlani, W De Graaff, T Oosterveen, B Roelen and J Roelfsema

Int. J. Dev. Biol. (1999) 43: 635-650

Genesis versus epigenesis: the odd jobs of the Polycomb group of genes. P Santamaría

Int. J. Dev. Biol. (1998) 42: 463-469

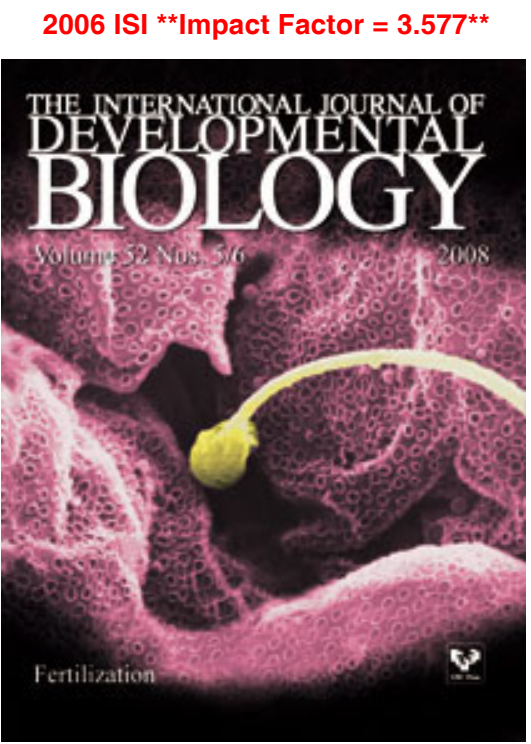

